\title{
BRIDGES TO CASH: \\ THE RETAIL END OF M-PESA
}

\section{Frederik EIJKMAN, JAKE KeNDALl and IGNACIO MAS*}

\begin{abstract}
M-PESA is a remarkably successful mobile payments system launched in Kenya three years ago. Users are able to send money to each other conveniently from their M-PESA using only their mobile phones. A key to the success of M-PESA is the availability of an extensive network of retail shops that accept M-PESA deposits and withdrawals, i.e. they stand ready to exchange cash and electronic value. It is the stores that provide liquidity to the system, and they are paid a commission by M-PESA for this service. Behind the store is a network of intermediaries that arrange the logistics around cash management. In this paper we look at daily transactional data from six M-PESA stores in Western Kenya supplemented by case studies and interviews of $M$ PESA store managers and employees in order to better understand the liquidity management needs of these stores. We examine how liquidity needs vary by location and day of week/month, and by the level of service offered by the store. We find that stores require intense daily management of liquidity to maintain customer service levels and that this is more difficult in rural areas. We also find some evidence of market discipline for agents who can't maintain service levels.
\end{abstract}

Keywords: Mobile Money, Agent Banking, M-PESA, Kenya, Agent Networks.

JEL Classification: G21, L81, L96, M2, M13, M15.

\section{INTRODUCTION}

M-PESA ("M" for mobile and "PESA" for money in Swahili) is a mobile money service promoted by Safaricom, the leading mobile operator in Kenya.

* Jake Kendall and Ignacio Mas are with the Financial Services for the Poor Team at the Bill \& Melinda Gates Foundation; Frederick Eijkman is co-founder of PEP Intermedius. The authors would like to thank Sheila Miller for being able editor and research assistant to this project and for her contributions to our thinking on key points. We owe the bridging analogy in the title of this paper to Paul Makin of Consult Hyperion. We are thankful for useful comments and suggestions from Crispin Bokea. 
The service provides a method of electronic payment accessible through mobile phones. Once customers deposit cash in their M-PESA accounts, they store the value as "e-float" - a form of electronic value issued by Safaricom until they are ready to use it for money transfers, buying airtime, or bill payments.

"De-materializing" cash into e-float offers benefits in terms of safety (reduced risk of theft or loss), convenience (less bulk, easier to send money remotely, lower transport costs, can purchase airtime and pay bills from the phone), and privacy. The core value proposition to customers is that M-PESA allows them to send money quickly and cheaply to distant business associates, friends, or relatives, a common need in Kenya where many families have some members working in urban areas ${ }^{1}$.

By solving this customer need, M-PESA has generated a large and loyal customer base. M-PESA is used by over $40 \%$ of Kenyan adults ${ }^{2}$ and more than $95 \%$ of users report that M-PESA is faster, safer, cheaper, or more convenient than alternative payment services like those provided by banks, ATMs, the post office, or money transfer services offered through bus companies $^{3}$. A full $84 \%$ of users claim that losing the service of M-PESA would have a large, negative effect on their lives.

The ability to quickly and conveniently withdraw cash or deposit cash is critical to achieving the high level of value that M-PESA delivers to its users. To access their accounts, customers exchange cash for e-float at a network of M-PESA retail stores (often referred to as sub-agents or agent points). There are some 16,000 agent points in Kenya, putting one within reach of most Kenyans. In fact many locations have multiple M-PESA agent points within a few hundred meters of each other. Keeping these agent points stocked with both cash (which they exchange for e-float in a withdrawal transaction) and e-float (which they exchange for cash in a deposit transaction) so that they can meet customers' needs for both deposits and withdrawals is a major challenge, and the subject of this article.

To document and understand the cash and liquidity needs of agents, we

1 De Laat (2005) documents that sending money through the post office costs $\$ 2.40$ for an average sized domestic remittance of $\$ 23$, and other alternatives were either more expensive or very inconvenient and slow, whereas a similar transaction on M-PESA would currently cost $\$ 0.37$ and happen instantly.

Additionally, the results of a survey of 3000 Kenyan households reported in Jack and Suri (2010a), show that only $16 \%$ of users report delays with the service and $34 \%$ are resolved in under an hour and only $9 \%$ take longer than a day to resolve.

2 FinAccess National Survey 2009.

3 Jack and Suri (2009). 
investigate data from 20 M-PESA stores in Western Kenya focusing on patterns in the flow of transactions with clients and in the trips to get cash or efloat. We supplement this data analysis with KII (key informant interviews) with staff of PEP Intermedius, M-PESA store owners and staff, and M-PESA clients.

Previous work on the M-PESA product has documented the role it plays in clients lives (see Morawczynski (2009)), and the fact that it had reached over $70 \%$ of households and over $50 \%$ of the poor, unbanked, and rural populations by the end of 2009 (see Jack and Suri (2010 a)). Additionally, Jack and Suri $(2010 \mathrm{~b})$ presents preliminary results from a survey indicating Kenyan households who have access to M-PESA and are close to an agent point are better able to maintain the level of consumption expenditures, and in particular food consumption, in the face of negative income shocks, such as job loss, livestock death, harvest or business failure, or poor health. On the other hand, households without access to M-PESA appear to be less able to absorb such adverse shocks. Though the results are preliminary, the researchers were careful to rule out explanations based on mere correlation, and are currently investigating the precise mechanisms that underlie this ability to spread risk (these investigations will appear in future work). If they hold up, these results are quite significant and demonstrate the importance of seeing further successes like M-PESA in other countries so that these development benefits can be extended to their populations.

While the risk mitigation results documented in Jack and Suri (2010 b) are most likely attributable to the money transfer feature of M-PEAS other experimental research, summarized in Kendall (2010), has shown that the ability to save, which is conveyed by M-PESA's e-wallet feature, can bring large welfare improvements to poor households under certain circumstances by enhancing their ability to save up and make productive investments. Further work will be needed to determine whether these hypothesized benefits are indeed being conveyed by M-PESA as well.

Setting up and running a mobile money system - of which M-PESA is the most successful example - confronts scheme operators with a series of difficult commercial challenges. These challenges are documented in Mas and Radcliffe (2010 a, b) and include: (i) network effects: When it comes to payment systems, the value of joining a network is directly proportional to the number of people already on it. (ii) Chicken-and-egg trap: In order to grow, these systems must aggressively attract both customers and cash-in/cashout merchants in tandem. Otherwise, merchants will stop offering the service due to low transaction revenue and customers won't join the system because they can't access a convenient outlet. (iii) Trust: Customers have to be- 
come comfortable going to non-bank retail outlets to meet their cash-in/out needs and initiating transactions through their mobile phones. Three key elements for success in launching and developing a mobile money service were identified in Mas and $\mathrm{Ng}^{\prime}$ weno (2010) and Davidson and Leishman (2010) as being (i) a strong and trustworthy brand, (ii) active management of the agent channel to build service points and maintain customer service, and (iii) proper pricing, which in the case of M-PESA implies charging where clients see most value, when money is sent to another person, or withdrawn after receipt. This paper contributes to this line of research by providing new data that documents the necessity for proper liquidity management and customer service for agents and the challenges of maintaining proper channel liquidity from the agent perspective.

In documenting the liquidity needs of agents, we seek to answers to some fundamental questions which have not been addressed in the other literature on mobile money.

First and foremost, we seek to understand the daily cash needs of agents? How frequently and in what quantities do they need to rebalance? A better understanding of agent liquidity needs is useful for commercial operators to understand the incentives that have to be in place to entice agents to bear the burden of liquidity management and may also be useful to the development community as an indirect measure of the importance of M-PESA in the local economy. We find that stores must rebalance on at least $60 \%$ of days (almost every day that they are open), and often several times per day implying large net cash in or cash out volume that is not necessarily balancing out at the store level. This represents a significant cost to stores, as a clerk must leave the store to carry or pick up cash.

A related goal is to understand the differences in the cash needs of agents across different types of stores (e.g. those in rural, urban, or semi-urban areas) and how do these differences relate to differences in transactional flows demanded by customers? We find significant differences between stores in the city center and other urban areas relative to rural stores. Rural stores appear to face special challenges as they have to deal with a triple whammy: (i) their commissions are typically lower because they handle fewer and smaller transactions; (ii) their transactions tend to be more lopsided towards cash out reflecting typical transfer patterns from urban to rural areas, so they have fewer opportunities for customer transactions naturally offsetting each other; and (iii) they tend to be located much further away from bank branches, which increases their travel and time costs each time they need to rebalance their liquidity.

Lastly, we look for evidence that competitive pressures between M-PESA 
stores who vie for the same customers act to improve service levels and prompt agents to keep adequate liquidity to meet customer needs? This question is especially important given the claims by some in the industry that service disruptions due to lack of agent liquidity and agents defrauding customers present a threat to consumers and warrant interventions in the name of consumer protection. The evidence here, while limited, shows that these worries may be unfounded. We find that customers face choice in their selection of M-PESA outlets as most stores are within 100 meters of another M-PESA outlet. Customers seem to exercise this choice deliberately, favoring certain stores offering exceptional service with substantial trading volumes despite their being other stores nearby. On the other hand, customers seem to punish stores that are not able to offer consistent service levels. The fact that most customers face a choice in which M-PESA agent they visit gives agents' the incentive to deliver high quality customer service.

In investigating these questions we also document a number of other interesting facts that emerge from the data including a large degree of seasonality and inter-month variation in the demand for M-PESA services, high demand on market days requiring extra trips for cash, and an imbalance between cash in and cash out transactions in rural and urban areas implying a net flow of funds from urban to rural areas.

\subsection{How M-PESA mobile money works}

To access the M-PESA service, customers must first register at an authorized M-PESA retail outlet. They are then assigned an individual electronic money account, or $e$-wallet, that is linked to their phone number and accessible through a SIM card-resident application on the mobile phone ${ }^{4}$. There is three-factor authentication of customers: through their mobile number (i.e. ownership of the SIM card inside the mobile phone), a user-selected personal identification number (PIN), and through their national ID card presented to the store teller at the time of the transaction.

M-PESA wallets are denominated in e-float backed $100 \%$ by liquid deposits held by Safaricom in fully regulated commercial banks - initially only the Commercial Bank of Africa (CBA), and now also Standard Chartered Bank (SCB). The interest from these balances accrues to a charitable foundation, and

4 The Subscriber Identification Module (SIM) card is a smart card found inside mobile phones that are based on the GSM family of protocols. The SIM card contains encryption keys, secures the user's PIN on entry, and drives the phone's menu. The Short Messaging Service (SMS) is a data messaging channel available on GSM phones. 
is not distributed to either Safaricom or M-PESA customers (the bulk of Safaricom's revenue from the M-PESA product comes from the fees it charges customers for money transfers). All transactions are authorized and recorded in real time using secure SMS, and are capped at the equivalent of US $\$ 500$.

Once transactions are confirmed, the account balances of sender and receiver are updated immediately to reflect the transfer, and the transferred funds are immediately available for use by the receiver. Both sender and receiver are sent an automated notification by the M-PESA server via text message confirming the transaction and stating their new account balances.

e-float is exchangeable for cash at designated M-PESA retail outlets. This is performed by pairing the handover of cash with an equal but opposite transfer of e-float between the M-PESA customer and the retailer. A deposit or cash in transaction entails a real-time transfer of e-float from the retailer to the customer in exchange for cash given to the retailer, while a withdrawal or cash out transaction requires that the customer transfer e-float to the retailer and receive cash in exchange. All e-float transfers - both cash in/out transactions and person to person (P2P) transfers between clients - are subject to availability of funds in the sender's account.

\subsection{Liquidity in the M-PESA network}

Given their higher frequency of transactions, retail outlets are given special e-wallets (or tills) with higher maximum account balances. This gives them more room for offsetting clients' cash-in transactions (which cause them to pay out e-float) and cash-out transactions (which cause them to accumulate e-float). Still, if the outlet performs too many cash-in transactions it will eventually run out of e-float, and if it performs too many cash out transactions it will run out of cash. In either case, the retailer will need to rebalance its liquidity: convert the excess e-float into cash, or vice versa. For that, they must go to the next rung up the cash distribution hierarchy.

Safaricom only buys and sells e-float from a select range of distributors (agents ${ }^{5}$ ) and banks (super-agents) with which it has signed an agency agreement. To buy (sell) e-float these agents must deposit (collect) the appropriate amount of money in (from) Safaricom's account at either of its custodian banks (CBA or SCB). Because of how the M-PESA system is set up and how interbank payments work in Kenya, it can take one or two days for such transactions to settle. Thus, the agent needs to have a sufficient balance of e-

5 The term agent can be confusing as it is often used interchangeably for the liquidity managers who contract with stores to manage their liquidity, and for the stores themselves. 
float to accommodate the potential liquidity needs of their stores for up to two days. This imposes a high working capital requirement cost on agents.

Agents in turn buy and sell e-float from the retail outlets (sub-agents) that depend from them. As with customers, a cash transaction between agent and sub-agent will be matched by an offsetting e-float transaction, with the agent taking the opposite side of whatever the store requires for its liquidity management purposes. The transfer of cash between the retailer and the agent may happen by the retailer visiting the agent's premises, or by the paying party depositing and withdrawing cash at the nearest bank branch where they both hold bank accounts. For the store, each rebalancing is likely to represent a trip, to either its agent head office or, more often, to the nearest bank branch. Additionally, if the transaction is done through a bank, the agent head office may also have to send an employee to the bank to deposit cash into the sub-agent's account, implying an extra cost to them.

Both retail outlets and agents are rewarded for their role in providing liquidity in the M-PESA system by Safaricom. They receive transaction commissions, so their income is directly proportional to the number of transactions they support. The average commission paid by Safaricom per cash in/out transaction is US $17 \not$ (pre-tax), of which the distributor will typically keep $20-30 \%$ and pass on the rest to the retail outlet. In many cases the MPESA business also brings indirect benefits to retail outlets beyond the commissions earned on M-PESA itself, in the form of increased foot traffic into the store and a reputational 'bump' from the store's association with the powerful Safaricom brand.

\subsection{The central importance of proper liquidity management for agent success}

For poor people who operate in a cash economy, and whose income comes in the form of small lumps of cash, being able to cash in and cash out easily is a precondition for participation in a system such as M-PESA. The M-PESA retail outlets are therefore the bridges between the entrenched cashbased exchange system and the new electronic payments cloud. This network of bridges needs to be sufficiently dense geographically to offer the necessary convenience to all customers, and sufficiently resilient to meet whatever cash or e-float needs customers may have at any time. Proper liquidity management of the retail network goes to the heart of the usefulness and the trustworthiness of the M-PESA proposition. For the retailers, keeping customers supplied with e-float and cash is central to their business. In section 5.3, we describe the case of a typical M-PESA store owner, Gaudencia, in her daily rounds to keep her stores supplied with liquidity. 


\subsection{Agent costs and risks in liquidity management}

For stores, managing liquidity is the central aspect of their business. The following are a list of the main obstacles reported by store employees and managers we interviewed in keeping enough cash and e-float on hand to satisfy customers:

Employee malfeasance: when rebalancing, store owners must almost always leave large amount of cash in the hands of employees, either by leaving the employee at the shop with the cash till, or by sending the employee to carry cash to or from their agent network manager or the bank branch. Stores report high employee turnover which exacerbates the challenge of trusting employees with cash.

Physical security: carrying and storing cash on their premises exposes owners and their employees to the risk of being robbed. In the PEP Intermedius network (see below for a description of PEP) of 106 stores, there were 10 reported robberies last year.

Working capital: shop owners must invest anywhere from US $\$ 2,000-\$ 4,000$ in e-float and cash. (PEP requires a minimum of US\$2,000 whereas the Safaricom minimum is closer to US\$600). This is significant sum to generate for a Kenyan small business owner.

Travel costs and time: as the story of Gaudencia (Section 5.3) illustrates, costs of transporting cash can be upwards of US $\$ 4-5$ dollars per day for a shop owner with multiple shops. Time is also a major factor, with some stores reporting 2 hours or more of round trip travel time.

\section{OUR SAMPLE OF M-PESA RETAIL OUTLETS}

This paper explores the liquidity needs of M-PESA outlets. We do so with the benefit of actual transactional data over a six-month period from a sample of 20 retail outlets managed by PEP Intermedius, an M-PESA agent operating in Western Kenya. This section describes the sample; in the next section we derive seven observations from the transactional data from these outlets which capture the essence of the agent business in Western Kenya. In the final section we derive three broad conclusions which follow from our analysis. These are the key factors that should be taken into account to ensure the sustainability of agent networks like M-PESA's. 


\subsection{About PEP Intermedius}

PEP Intermedius is a private company owned partially by its two founders (one of whom, Frederik Eijkman, is a co-author of this paper). Its primary business is as a M-PESA agent, and it has a side-business in microcredit. PEP was founded in 2004 to do microfinance. However, having felt that the primary need of the local population was convenient and affordable cash availability, PEP began operating as an agent of M-PESA in 2007 when the service was launched. PEP has its headquarters office in Kisumu on Lake Victoria, and has 16 employees.

In its M-PESA business, PEP manages a total of 106 retail outlets, of which 8 are fully owned by PEP and the remainder are franchised (these are third party stores that conduct their M-PESA business through PEP as their agent).

Originally PEP opened their own stores targeting strategic locations. However they report that they soon found that they could not keep up with the spread of other agent points due to the costs of finding, building, and staffing their own stores. This prompted the move to a franchise approach where they would accommodate store owners with the necessary capital allowing them to start on their own. The franchise model gave PEP an opportunity to expand rapidly and reduce the risks associated with store ownership and cash transit.

\subsection{Introducing our sample of 20 stores}

We started by defining four archetypal types of stores, based on their location and the kinds of clientele they attract:

- City: These are stores in the central business district of the provincial capital, Kisumu. The customers are typically white collar employees who work in the city center, as well as business people and out of town visitors who are in Kisumu for business, to make purchases, or to deal with government offices.

- Urban: These are stores located in or around two main markets, of which one near the main bus terminal and in Kisumu. There are many M-PESA agents within 100 meters of each other. Typical customers include local shop owners, travelers who are coming and going by bus, and wholesale traders who are in the market to buy or sell vegetables, fruits, and other goods for sales elsewhere.

- District: These are stores in provincial market towns located on the main highways connecting Kisumu with Nairobi and other major towns in the 
region. These towns are not very populous but their markets get very busy with many traders and visitors coming from nearby rural villages to make purchases and conduct business.

- Rural: These are stores in small towns with a population of around 5,000. They are often visited by rural customers from surrounding areas that do not have the money to travel to larger towns. These towns typically have only a few permanent structures housing mainly shops selling the most basic commodities and workshops for local artisans (carpenters, etc).

Figure 1 shows the location of the towns with stores in our sample within Western Kenya (marked with the PEP logo). Figure 2 lists the twenty stores in our sample, and offers some descriptive characteristics for each. M-PESA constitutes the main business for all the stores. Most have been offering MPESA for at least two years. All but two stores have a competitor within 100 meters.

Figure 1: Locations of PEP stores in our sample, around Kisumu near Lake Victoria in Western Kenya

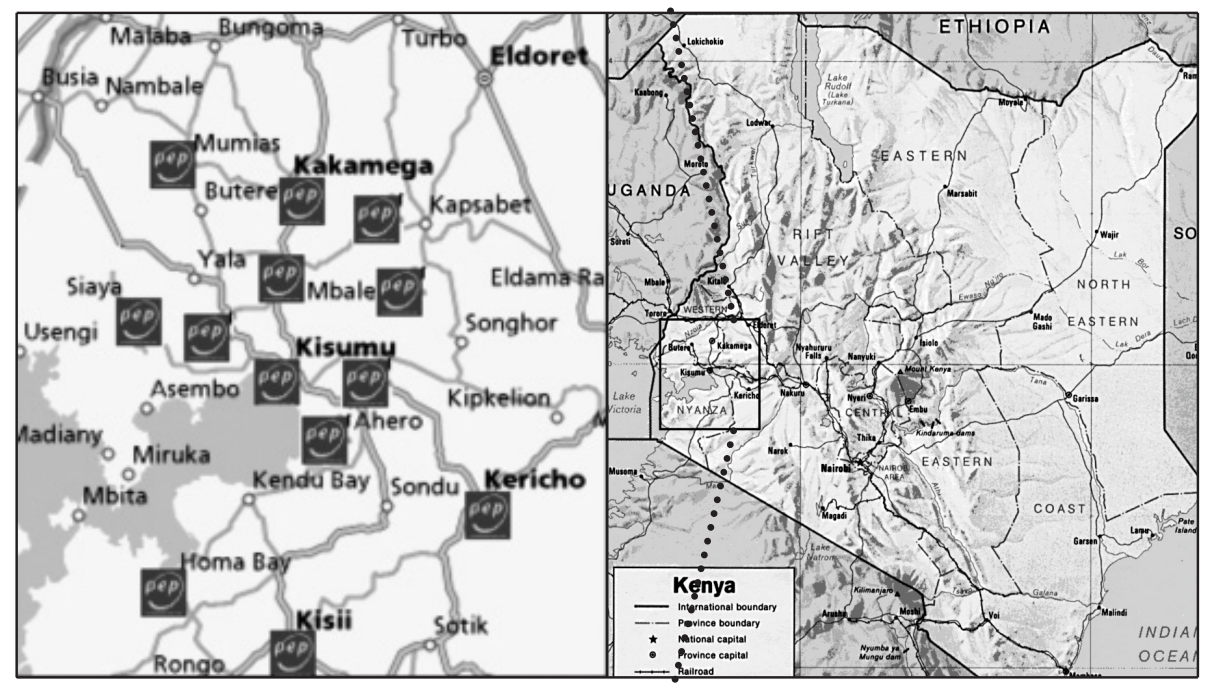

All the ten stores in Kisumu (those in the urban and city categories) rebalance their liquidity by going into the PEP headquarters in downtown Kisumu. The most distant one is 2 kilometers away, but the majority is within 10 to 15 minutes of PEP headquarters. Half the stores outside of Kisumu 
are in towns with a bank branch and are able to rebalance their liquidity locally. However, four stores are 20-60 kilometers away from the nearest branch. For these distant stores, cash management is especially difficult. Shop owners have to leave the management of the store in the hands of an employee, or send an employee to rebalance. In either case, the manager will be faced with leaving the employee alone with cash representing a large multiple of their monthly salary. Additionally, round trip travel time can be an hour or more at a round trip cost of US\$2-3.

For each store in the sample, we collected daily M-PESA transaction data for the period of July 2009 to December 2009. Figure 3 shows some summary trading statistics for each store. The first five numerical columns relate to MPESA transactions undertaken by clients: the average daily value of transactions, the average daily number of deposit (cash in) and withdrawals (cash out), and the average deposit and withdrawal transaction sizes. The last column is the average number of liquidity rebalancing transactions each store conducted daily with PEP as their M-PESA agent.

Figure 2: A snapshot of the 20 stores in the sample

\begin{tabular}{|c|c|c|c|c|c|c|c|}
\hline Store & $\begin{array}{c}\text { Name of } \\
\text { town \& } \\
\text { population }\end{array}$ & $\begin{array}{c}\text { Type of } \\
\text { location \& } \\
\text { ownership }\end{array}$ & $\begin{array}{c}\text { Distance } \\
\text { to nearest } \\
\text { M-PESA shop }\end{array}$ & $\begin{array}{c}\text { Distance } \\
\text { to bank or } \\
\text { PEP HQ }\end{array}$ & $\begin{array}{c}\text { Main/side } \\
\text { business } \\
\text { of Store }\end{array}$ & $\begin{array}{l}\text { Store } \\
\text { Location }\end{array}$ & $\begin{array}{l}\text { Time } \\
\text { as } \\
\text { agent }\end{array}$ \\
\hline Ahero & $\begin{array}{l}\text { Ahero } \\
\text { 10k pop }\end{array}$ & $\begin{array}{l}\text { District, } \\
\text { franchise }\end{array}$ & $5 \mathrm{~m}$ & $\begin{array}{l}60 \mathrm{~min} / \\
25 \mathrm{~km}\end{array}$ & M-PESA & Kiosk & $2 \mathrm{yrs}$ \\
\hline $\begin{array}{l}\text { Cash } \\
\text { Joint }\end{array}$ & $\begin{array}{c}\text { Kisumu } \\
\text { 350k pop }\end{array}$ & $\begin{array}{c}\text { City, } \\
\text { franchise }\end{array}$ & $10 \mathrm{~m}$ & $\begin{array}{l}200 \mathrm{~m} \\
\text { to PEP }\end{array}$ & M-PESA & Kiosk & $2.5 \mathrm{yrs}$ \\
\hline $\begin{array}{l}\text { Cyber } \\
\text { Centre }\end{array}$ & $\begin{array}{l}\text { Kisumu } \\
\text { 350k pop }\end{array}$ & $\begin{array}{l}\text { Urban, } \\
\text { franchise }\end{array}$ & $50 \mathrm{~m}$ & $\begin{array}{l}15 \mathrm{~min} \\
\text { to PEP }\end{array}$ & $\begin{array}{c}\text { M-PESA } \\
\text { Beauty } \\
\text { prods. }\end{array}$ & Kiosk & $2 \mathrm{yrs}$ \\
\hline Flamagras & $\begin{array}{l}\text { Kisumu } \\
\text { 350k pop }\end{array}$ & $\begin{array}{c}\text { City, } \\
\text { franchise }\end{array}$ & $40 \mathrm{~m}$ & $\begin{array}{l}400 \mathrm{~m} \\
\text { to PEP }\end{array}$ & $\begin{array}{c}\text { M-PESA } \\
\text { Hair saloon }\end{array}$ & Store & $2.5 \mathrm{yrs}$ \\
\hline Homa Bay & $\begin{array}{l}\text { Homa Bay } \\
\text { 20k pop }\end{array}$ & $\begin{array}{l}\text { District, } \\
\text { owned }\end{array}$ & $6 \mathrm{~m}$ & $\begin{array}{l}5 \mathrm{~min} \\
\text { to Bank }\end{array}$ & M-PESA & Kiosk & 3 yrs \\
\hline Jubilee & $\begin{array}{c}\text { Kisumu } \\
\text { 350k pop }\end{array}$ & $\begin{array}{l}\text { Urban, } \\
\text { franchise }\end{array}$ & $50 \mathrm{~m}$ & $\begin{array}{l}15 \mathrm{~min} \\
\text { to PEP }\end{array}$ & M-PESA & Kiosk & $2 \mathrm{yrs}$ \\
\hline Katito & $\begin{array}{l}\text { Katito } \\
5 \mathrm{k} \text { pop }\end{array}$ & $\begin{array}{l}\text { Rural, } \\
\text { franchise }\end{array}$ & $100 \mathrm{~m}$ & $\begin{array}{l}\text { 60min } \\
\text { to PEP }\end{array}$ & $\begin{array}{l}\text { M-PESA } \\
\text { Sodas }\end{array}$ & Store & $1 \mathrm{yr}$ \\
\hline
\end{tabular}




\begin{tabular}{|c|c|c|c|c|c|c|c|}
\hline Store & $\begin{array}{c}\text { Name of } \\
\text { town \& } \\
\text { population }\end{array}$ & $\begin{array}{c}\text { Type of } \\
\text { location \& } \\
\text { ownership }\end{array}$ & $\begin{array}{c}\text { Distance } \\
\text { to nearest } \\
\text { M-PESA shop }\end{array}$ & $\begin{array}{l}\text { Distance } \\
\text { to bank or } \\
\text { PEP HQ }\end{array}$ & $\begin{array}{c}\text { Main/side } \\
\text { business } \\
\text { of Store }\end{array}$ & $\begin{array}{c}\text { Store } \\
\text { Location }\end{array}$ & $\begin{array}{l}\text { Time } \\
\text { as } \\
\text { agent }\end{array}$ \\
\hline Kibuye & $\begin{array}{c}\text { Kisumu } \\
\text { 350k pop }\end{array}$ & $\begin{array}{l}\text { Urban, } \\
\text { franchise }\end{array}$ & $50 \mathrm{~m}$ & $\begin{array}{l}15 \mathrm{~min} \\
\text { to PEP }\end{array}$ & M-PESA & Kiosk & $2 \mathrm{yrs}$ \\
\hline $\begin{array}{l}\text { Lake } \\
\text { Market }\end{array}$ & $\begin{array}{c}\text { Kisumu } \\
\text { 350k pop }\end{array}$ & $\begin{array}{c}\text { City, } \\
\text { franchise }\end{array}$ & $10 \mathrm{~m}$ & $\begin{array}{l}150 \mathrm{~m} \\
\text { to PEP }\end{array}$ & $\begin{array}{c}\text { M-PESA } \\
\text { Beauty } \\
\text { prods. }\end{array}$ & Kiosk & $2.5 \mathrm{yrs}$ \\
\hline Luanda & $\begin{array}{l}\text { Luanda } \\
\text { 10k pop }\end{array}$ & $\begin{array}{l}\text { District, } \\
\text { owned }\end{array}$ & $5 \mathrm{~m}$ & $\begin{array}{l}5 \mathrm{~min} \\
\text { to Bank }\end{array}$ & M-PESA & Store & $2.5 \mathrm{yrs}$ \\
\hline Noble & $\begin{array}{c}\text { Kisumu } \\
\text { 350k pop }\end{array}$ & $\begin{array}{c}\text { City, } \\
\text { franchise }\end{array}$ & $50 \mathrm{~m}$ & $\begin{array}{l}200 \mathrm{~m} \\
\text { to PEP }\end{array}$ & $\begin{array}{c}\text { M-PESA } \\
\text { Photo } \\
\text { copying }\end{array}$ & Store & $2.5 \mathrm{yrs}$ \\
\hline Nyagande & $\begin{array}{c}\text { Nyagande } \\
5 \mathrm{k} \text { pop }\end{array}$ & $\begin{array}{c}\text { Rural, } \\
\text { franchise }\end{array}$ & $300 \mathrm{~m}$ & $\begin{array}{l}90 \mathrm{~min} \\
30 \mathrm{~km}\end{array}$ & M-PESA & Kiosk & $1 \mathrm{yr}$ \\
\hline One Stop & $\begin{array}{c}\text { Kisumu } \\
\text { 350k pop }\end{array}$ & $\begin{array}{l}\text { Urban, } \\
\text { franchise }\end{array}$ & $50 \mathrm{~m}$ & $\begin{array}{l}15 \mathrm{~min} \\
\text { to PEP }\end{array}$ & $\begin{array}{c}\text { M-PESA } \\
\text { Photo } \\
\text { copying }\end{array}$ & Kiosk & $2 \mathrm{yrs}$ \\
\hline $\begin{array}{c}\text { Paw } \\
\text { Akuche }\end{array}$ & $\begin{array}{c}\text { Holo } \\
5 \mathrm{k} \text { pop }\end{array}$ & $\begin{array}{l}\text { Rural, } \\
\text { owned }\end{array}$ & $100 \mathrm{~m}$ & $\begin{array}{l}45 \mathrm{~min} \\
20 \mathrm{~km}\end{array}$ & M-PESA & Store & $2.5 \mathrm{yrs}$ \\
\hline PEP HQ & $\begin{array}{l}\text { Kisumu } \\
\text { 350k pop }\end{array}$ & $\begin{array}{c}\text { City, } \\
\text { owned }\end{array}$ & & 0 to PEP & $\begin{array}{c}\text { M-PESA } \\
\text { Micro } \\
\text { lending }\end{array}$ & Office & $3 \mathrm{yrs}$ \\
\hline Serem & $\begin{array}{l}\text { Serem } \\
\text { 10k pop }\end{array}$ & $\begin{array}{l}\text { Rural, } \\
\text { franchise }\end{array}$ & $50 \mathrm{~m}$ & $\begin{array}{l}5 \mathrm{~min} \\
\text { to Bank }\end{array}$ & M-PESA & Store & $1 \mathrm{yr}$ \\
\hline Shop 786 & $\begin{array}{c}\text { Kisumu } \\
\text { 350k pop }\end{array}$ & $\begin{array}{l}\text { Urban, } \\
\text { franchise }\end{array}$ & $50 \mathrm{~m}$ & $\begin{array}{l}15 \mathrm{~min} \\
\text { to PEP }\end{array}$ & M-PESA & Store & $2 \mathrm{yrs}$ \\
\hline Siaya & $\begin{array}{c}\text { Siaya } \\
\text { 20k pop }\end{array}$ & $\begin{array}{l}\text { District, } \\
\text { owned }\end{array}$ & $300 \mathrm{~m}$ & $\begin{array}{l}5 \mathrm{~min} \\
\text { to Bank }\end{array}$ & M-PESA & Store & $3 \mathrm{yrs}$ \\
\hline Usenge & $\begin{array}{l}\text { Usenge } \\
5 \mathrm{k} \text { pop }\end{array}$ & $\begin{array}{c}\text { Rural, } \\
\text { franchise }\end{array}$ & $100 \mathrm{~m}$ & $\begin{array}{l}2 \mathrm{hrs} \\
60 \mathrm{~km}\end{array}$ & M-PESA & Kiosk & $1 \mathrm{yr}$ \\
\hline Vihiga & $\begin{array}{c}\text { Mbale } \\
\text { 20k pop }\end{array}$ & $\begin{array}{l}\text { District, } \\
\text { owned }\end{array}$ & $20 \mathrm{~m}$ & $\begin{array}{l}5 \mathrm{~min} \\
\text { to Bank }\end{array}$ & M-PESA & Store & $3 \mathrm{yrs}$ \\
\hline
\end{tabular}




\section{Figure 3: Summary tradings statistics for the 20 stores in our sample}

\begin{tabular}{|c|c|c|c|c|c|c|c|}
\hline \multirow[b]{2}{*}{ Store Name } & \multirow[b]{2}{*}{ Location } & \multirow{2}{*}{$\begin{array}{c}\text { Average } \\
\text { Daily } \\
\text { Volume }\end{array}$} & \multicolumn{2}{|c|}{ Deposits } & \multicolumn{2}{|c|}{ Withdrawals } & \multirow{2}{*}{$\begin{array}{c}\text { PEP } \\
\text { Transactions } \\
\text { Ave. \# / day }\end{array}$} \\
\hline & & & $\begin{array}{c}\text { Ave.\#/ } \\
\text { day }\end{array}$ & $\begin{array}{c}\text { Ave. Tx. } \\
\text { Size }\end{array}$ & $\begin{array}{c}\text { Ave.\#/ } \\
\text { day }\end{array}$ & $\begin{array}{c}\text { Ave. Tx. } \\
\text { Size }\end{array}$ & \\
\hline Cash Joint & city & $\$ 7,210$ & 90 & $\$ 54$ & 58 & $\$ 40$ & 2.9 \\
\hline Flamagras & city & $\$ 3,003$ & 37 & $\$ 52$ & 25 & $\$ 42$ & 2.7 \\
\hline Lake Market & city & $\$ 14,532$ & 126 & $\$ 78$ & 82 & $\$ 55$ & 4.6 \\
\hline Noble & city & $\$ 2,105$ & 30 & $\$ 41$ & 21 & $\$ 41$ & 0.6 \\
\hline PepHQ & city & $\$ 3,136$ & 22 & $\$ 86$ & 16 & $\$ 77$ & 1.4 \\
\hline Ahero & district & $\$ 5,001$ & 29 & $\$ 36$ & 107 & $\$ 37$ & 2.7 \\
\hline Homa Bay & district & $\$ 4,316$ & 38 & $\$ 58$ & 33 & $\$ 64$ & 0.4 \\
\hline Luanda & district & $\$ 3,023$ & 4 & $\$ 13$ & 103 & $\$ 29$ & 1.8 \\
\hline Siaya & district & $\$ 3,148$ & 12 & $\$ 41$ & 50 & $\$ 53$ & 1.6 \\
\hline Vihiga & district & $\$ 3,311$ & 24 & $\$ 36$ & 71 & $\$ 35$ & 1.4 \\
\hline Katito & rural & $\$ 2,313$ & 31 & $\$ 27$ & 88 & $\$ 17$ & 1.1 \\
\hline Nyagande & rural & $\$ 853$ & 6 & $\$ 18$ & 38 & $\$ 19$ & 0.5 \\
\hline Paw Akuche & rural & $\$ 2,390$ & 11 & $\$ 22$ & 65 & $\$ 33$ & 1.7 \\
\hline Serem & rural & $\$ 3,250$ & 19 & $\$ 41$ & 74 & $\$ 34$ & 1.2 \\
\hline Usenge & rural & $\$ 1,314$ & 11 & $\$ 37$ & 19 & $\$ 57$ & 0.3 \\
\hline Cyber Centre & urban & $\$ 6,594$ & 86 & $\$ 38$ & 88 & $\$ 38$ & 2.4 \\
\hline Jubilee Market & urban & $\$ 2,239$ & 43 & $\$ 31$ & 35 & $\$ 26$ & 1.6 \\
\hline Kibuye & urban & $\$ 2,667$ & 42 & $\$ 28$ & 47 & $\$ 31$ & 1.1 \\
\hline OneStop & urban & $\$ 2,154$ & 25 & $\$ 44$ & 25 & $\$ 42$ & 0.6 \\
\hline Shop 786 & urban & $\$ 3,203$ & 43 & $\$ 34$ & 53 & $\$ 33$ & 1.1 \\
\hline Average & city & $\$ 5,997$ & $\$ 61$ & $\$ 62$ & $\$ 40$ & $\$ 51$ & $\$ 2$ \\
\hline Average & district & $\$ 3,760$ & $\$ 21$ & $\$ 37$ & $\$ 73$ & $\$ 44$ & $\$ 2$ \\
\hline Average & rural & $\$ 2,024$ & $\$ 16$ & $\$ 29$ & $\$ 57$ & $\$ 32$ & $\$ 1$ \\
\hline Average & urban & $\$ 3,371$ & $\$ 47$ & $\$ 35$ & $\$ 50$ & $\$ 34$ & $\$ 1$ \\
\hline Average & Full Sample & $\$ 3,788$ & $\$ 36$ & $\$ 41$ & $\$ 55$ & $\$ 40$ & $\$ 2$ \\
\hline
\end{tabular}

* Note: Volumes in $\$(75 \mathrm{Ksh}=\$ 1)$.

These averages were calculated excluding sundays when most stores are closed. 


\section{STYLIZED OBSERVATIONS FROM THE STORE TRADING DATA}

The analysis of daily transaction data for the stores in our sample revealed seven key patterns and stylized facts. We discuss the broader implications of these facts in greater depth in the conclusion.

\subsection{Agent liquidity management is costly: stores need to rebalance their liquidity holdings daily}

Figure 4: Number of transactions with PEP per store per trading day, by type of store

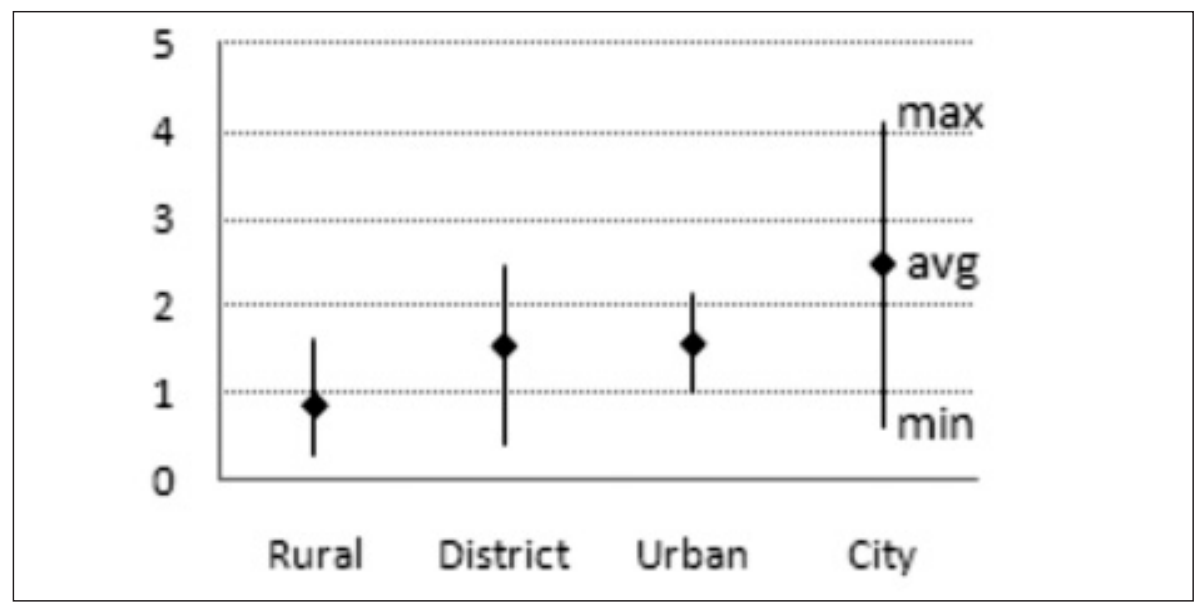

Most stores make at least one daily journey to rebalance the M-PESA agent's holding of cash and float. Figure 4 shows the frequency with which outlets must rebalance their cash holdings by buying or selling e-float from PEP. Stores in rural markets do so on average daily, stores in district and urban markets do so on average 1.5 times per day, and stores in the city centre do so on average 2.5 times a day. Looking at individual stores, there is a lot of variance, especially for city centre stores as one of them had to rebalance as much as four times per day on average.

Figure 5 looks at the store rebalancing frequency in more detail. On average, all types of stores avoid having to rebalance their liquidity on around $40 \%$ of days (these include many weekend days when stores are not open or face slower demand $)^{6}$. Of the remaining $60 \%$ of days, stores in rural mar-

6 PEP HQ is open and available for transactions 7 days a week. 
Figure 5: Frequency with which stores transact with PEP per trading day, by type of store

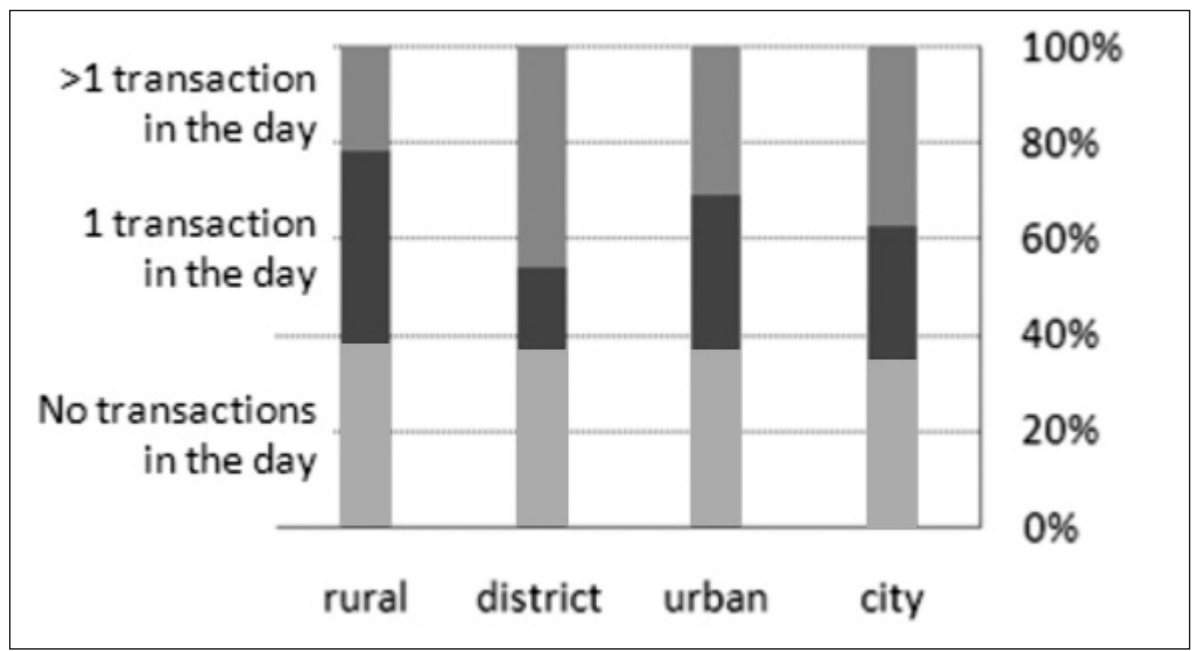

kets are twice more likely to have to rebalance only once in the day, whereas for the other types of store they are more likely to have to rebalance more than once in the day. District stores are the ones which most frequently need to rebalance twice a day or more, owing partly to the larger transaction sizes.

For rural stores, where remittances drive a predictable need for cash every day, store owners or employees often make a trip in the morning to exchange the e-float built up the previous day with cash for the coming day. For rural and district stores at a great distance to PEP or a bank branch, this often implies an hour or two of travel time each way and so they often arrive at 10 or 11 am to get cash at PEP and return to the village. For these distant stores, multiple trips per day are prohibitively time consuming so they do their best to make just one per day. In the city and urban areas, most stores are a 5-10 minute walk from PEP HQ and so can make frequent trips throughout the day. This is fortunate, because the city and urban center stores also face more uncertain cash needs, sometimes needing to sell e-float for cash, and sometimes needing to buy more e-float. In these stores, just a few large transactions by, e.g. merchants paying their suppliers, can tip the balance one way or the other triggering a trip to PEP. Section 5.1 describes three actual trips to get cash and the costs and difficulties associated with each. 
2. Rural areas do fewer and smaller transactions; in the city center transactions are much larger

Figure 6: Average number of client transactions per store per trading day

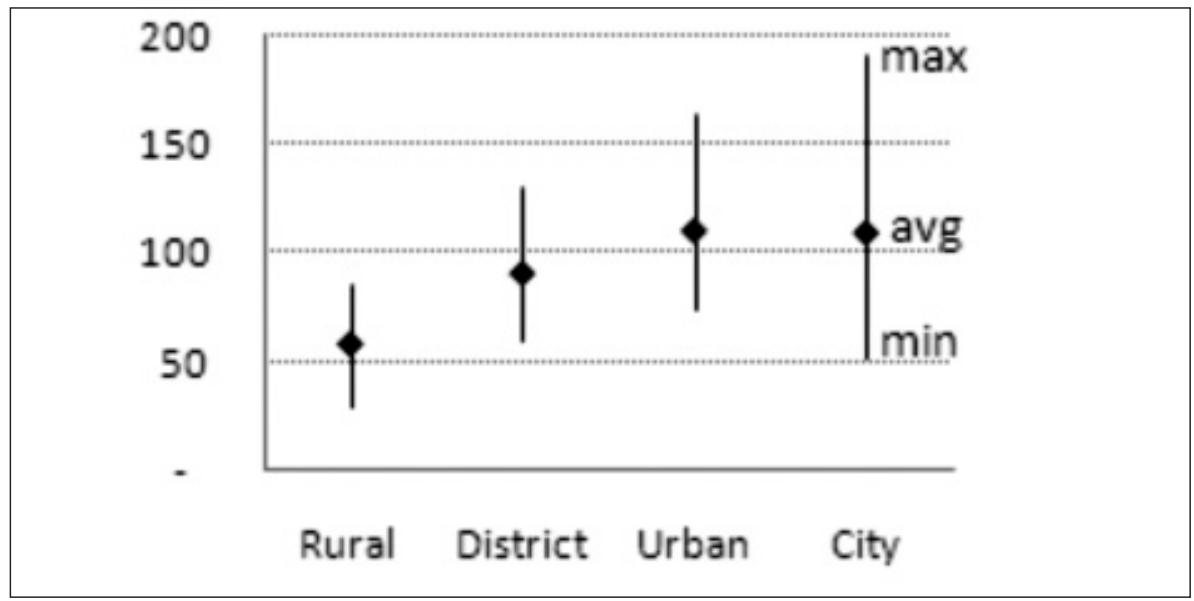

Figure 7: Average client transaction size, in Ksh

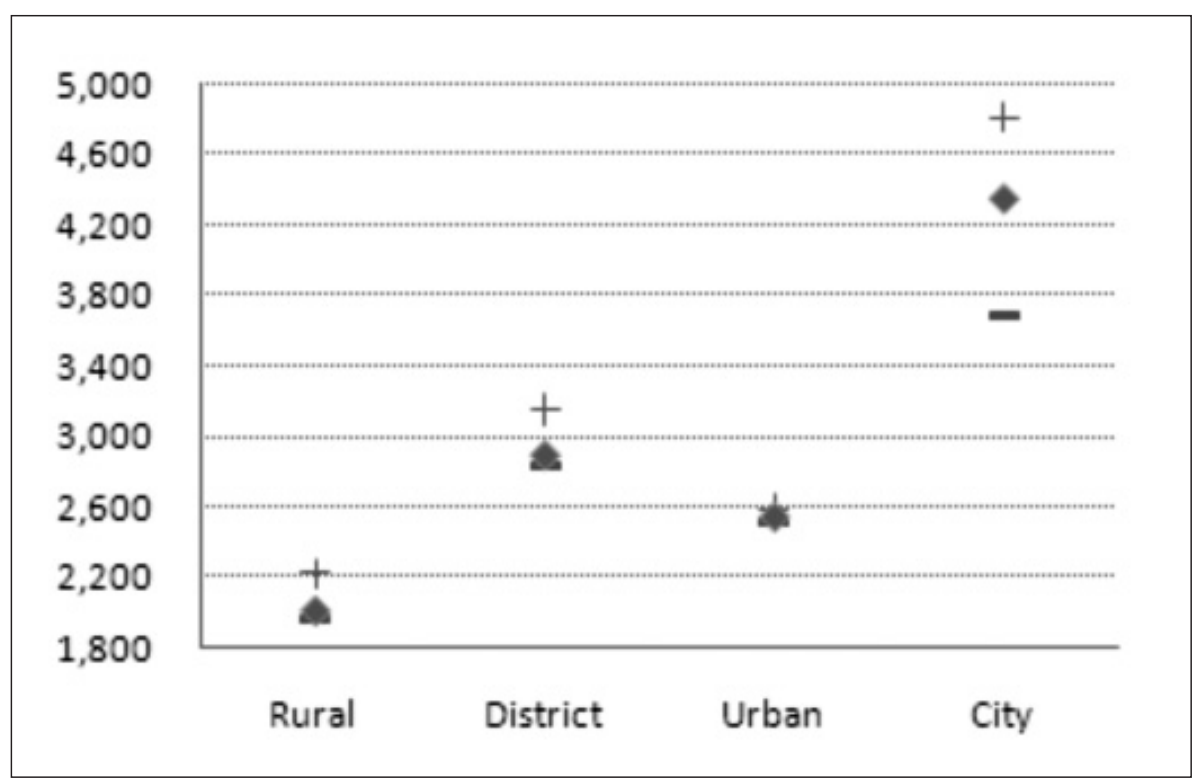


Figure 6 shows the average number of client transactions stores do in a typical day. While a typical rural market store does just over 50 transactions per day, stores in Kisumu (urban and city) do twice as many. District stores located in busy road-side markets transact volumes that are closer to the urban markets. There is also a much wider range of transactions by store in Kisumu which reflects the greater variety of customer needs. In rural areas, most customers are villagers receiving similarly sized remittances from city relatives, whereas in the city center stores, the transactions of contractors, small businesses, merchants, and traders are mixed in with remittance transactions.

At a commission of roughly $10 \notin$ per transaction accruing after tax to the store, this volume of business translates into daily revenue to the store of US\$5 for rural stores doing 50 transactions daily and US\$10 for stores doing 100 transactions. At the very upper end of the range, Lake Market store in the city center averaged over US\$30 a day on its best month (See Section 5.2 for more on Lake Market).

Figure 7 shows the average M-PESA transaction size in Kenyan shilling that stores undertake on behalf of their customers. Predictably, stores in rural markets tend to do much smaller transactions, averaging 2,000Ksh (US\$27). Typical transactions at city centre stores are more than double this amount, reflecting the fact that many merchants and traders use M-PESA to pay suppliers or contractors and receive payment for large volumes of goods. Transaction sizes are larger in district towns than in urban stores largely due to the fact that markets in towns are weekly rather than daily implying that customers are making bulk purchases to satisfy their needs for the week. In urban areas, customers tend to be richer but are usually transacting to satisfy daily shopping needs rather than weekly. Cash in and cash out transactions tend to be of very similar sizes on average, except for city centre stores where cash in transactions are typically 30\% larger in size than cash out transactions. One factor driving these larger cash in transactions is the large payments made by merchants to suppliers and workers.

\section{Reflecting domestic remittance patterns, rural areas are strongly cash out, whereas urban areas tend to be more cash in}

Figure 8 shows the average daily value of client transactions at different types of stores. Stores in rural markets trade on average $172,000 \mathrm{Ksh}$ (US\$2,300) per day, of which $90 \%$ is cash out. District market stores typically trade twice as much, but still have a preponderance of cash out. Stores in urban markets are roughly balanced between cash in and cash out, while stores 
Figure 8: Average daily values of client transactions in Ksh '000

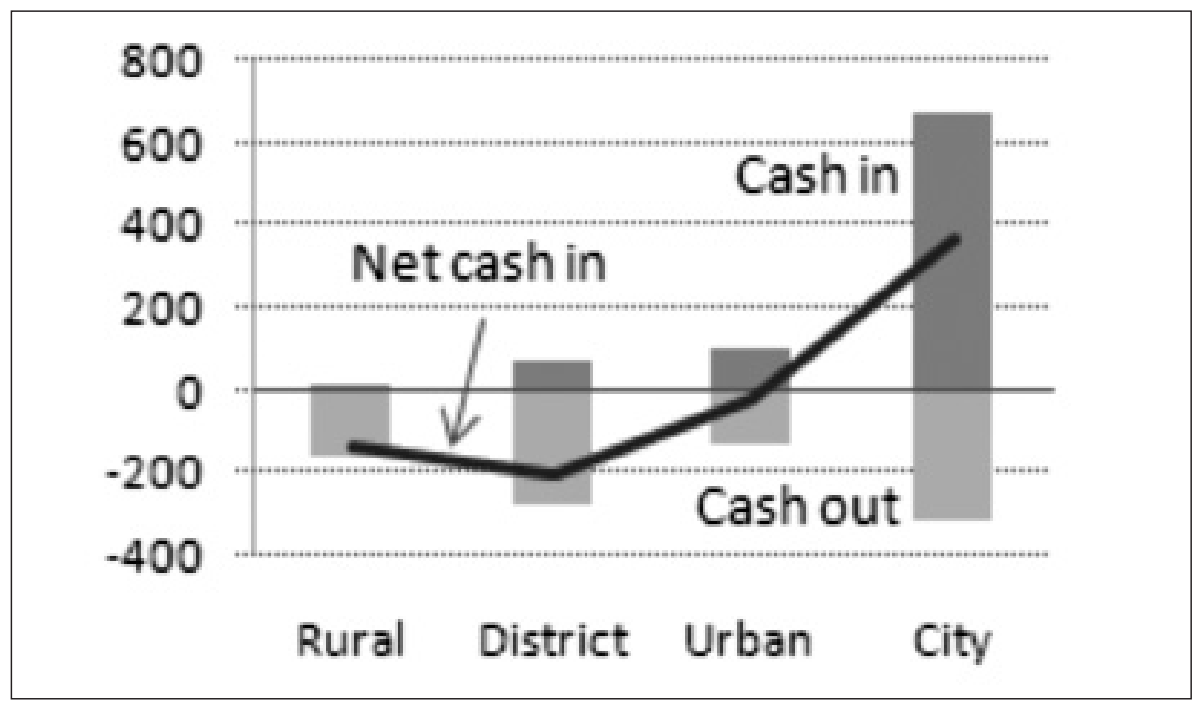

Figure 9: Frequency of days in which stores need to rebalance their liquidity holdings with PEP

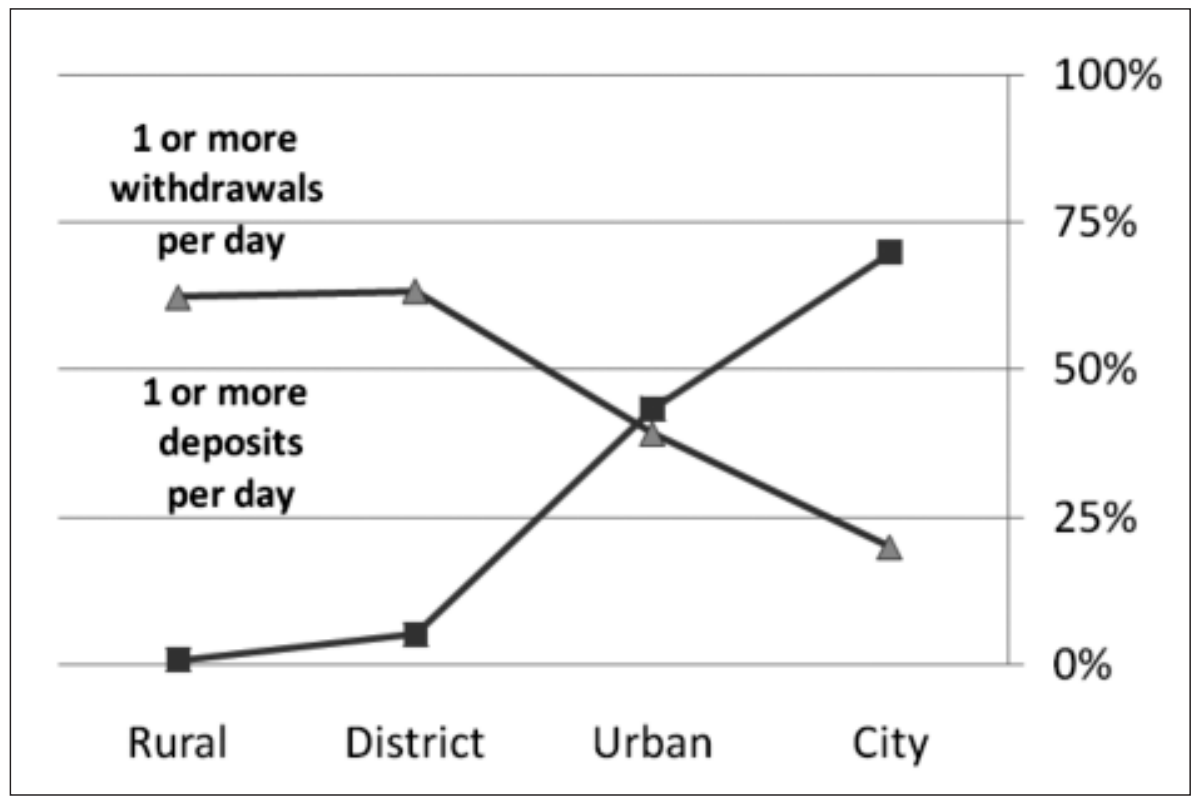


in Kisumu city centre trade much larger volumes $(360,000 \mathrm{Ksh}$ or US $\$ 13,000)$ and are predominantly used for cash in. This shows that a fundamental trend in M-PESA usage is to transfer balances from city to rural environments.

Figure 9 looks at the implications of this spatial differentiation between stores in terms of their liquidity rebalancing requirements. Most stores do need to rebalance daily, ranging from $76 \%$ of days for city centre stores to $62 \%$ for rural stores). Stores in rural markets need to sell e-float from PEP (withdraw cash), while stores in the city centre need to buy e-float from PEP (deposit cash) much more often.

Figure 10: Average total daily transaction size for urban stores

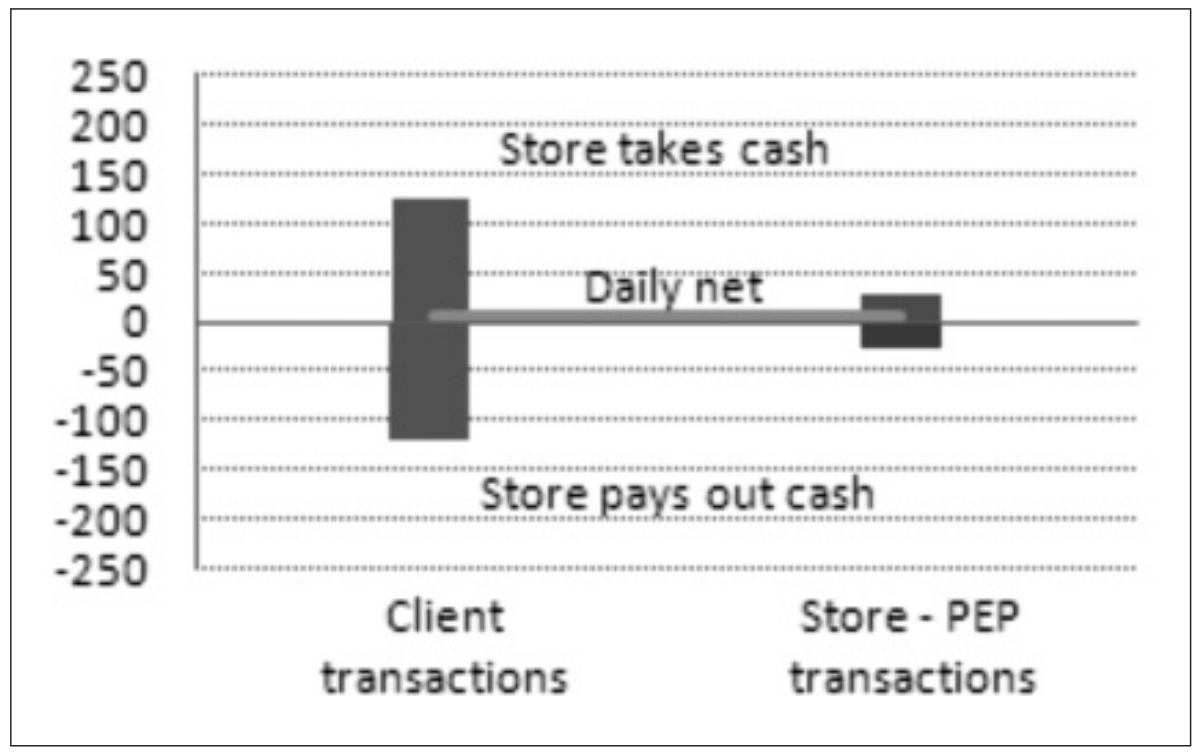

Figure 10 looks more closely at the trading patterns of urban stores. The daily net cash in/out from customers' transactions is essentially zero, and this matches the daily net rebalancing transactions with PEP. However, this balance masks intra-day variations in the types of customer transactions undertaken. Figure 11 shows that for urban and city-centre stores, they needed to rebalance their liquidity at least twice, once buying and once selling efloat to PEP on almost $20 \%$ of days. Partly, urban and city stores have the luxury of more frequent rebalancing, given their proximity to PEP, but they are also less able to predict net cash needs given the greater variance in 


\section{Figure 11: Percentage of days when agent both deposited} AND withdrew from PEP on the same day

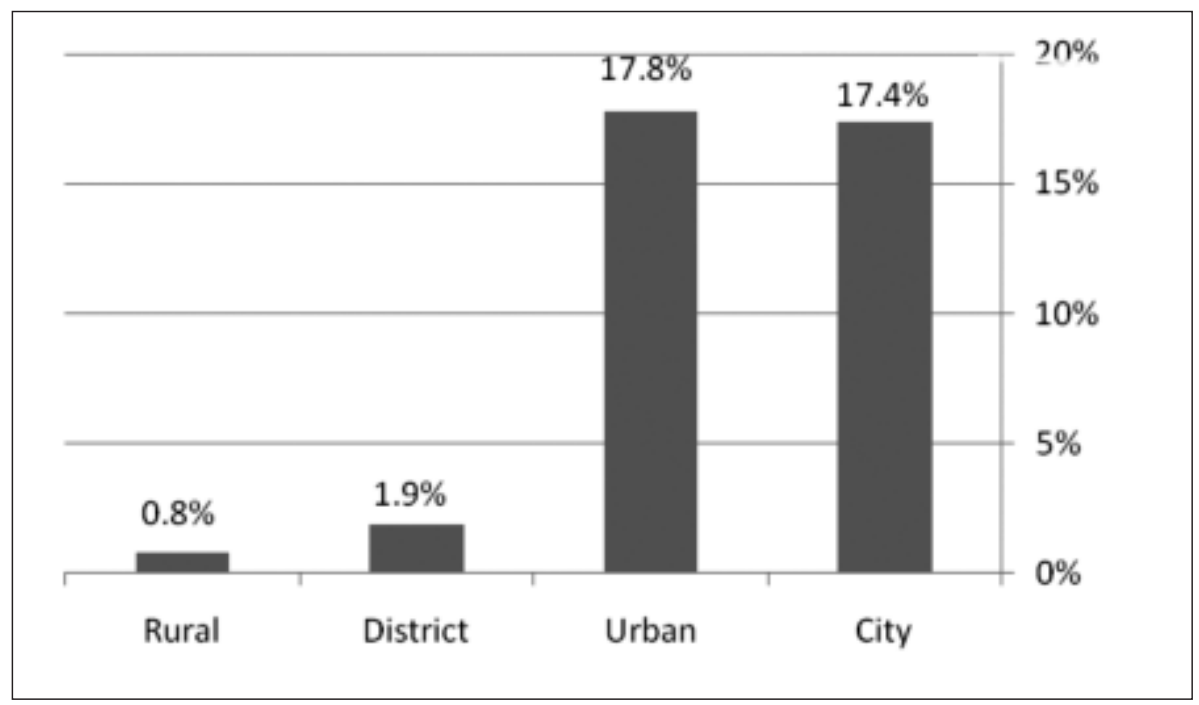

transaction sizes and more even mix of cash in with cash out ${ }^{7}$. By contrast rural and district stores almost always need to fund excess cash withdrawals and thus have a predictable need for cash.

\section{Rural and District stores hold more float at the end of the day}

Figure 12 shows the e-float remaining at the end of the day, as a percentage of the stores' average daily transaction volume, which is over $70 \%$ for rural stores. The rural stores are essentially cash salesmen who sell cash throughout the day to build up a stock of e-float, which they then trade in again for cash the next morning (see also Figure 8$)^{8}$. In contrast, the urban

7 In the city center there are more wage earners sending money home, thus the greater number of cash in transactions. Additionally, many small businesses, traders, and contractors use M-PESA to pay employees, suppliers, and each other which drives larger transactions both cash in and cash out.

8 Conversations with PEP staff revealed that district stores would also have had a higher average end-of-day balance relative to transaction volume, nearer to the $70 \%$ that rural stores have, except that many of the district stores in our sample are PEP-owned and therefore transfer their e-float balance to PEP at the end of the day so that their merchant account is basically empty when employees go home. 
Figure 12: End of day float as a percentage of the store's average daily transaction volumes - averaged by store type

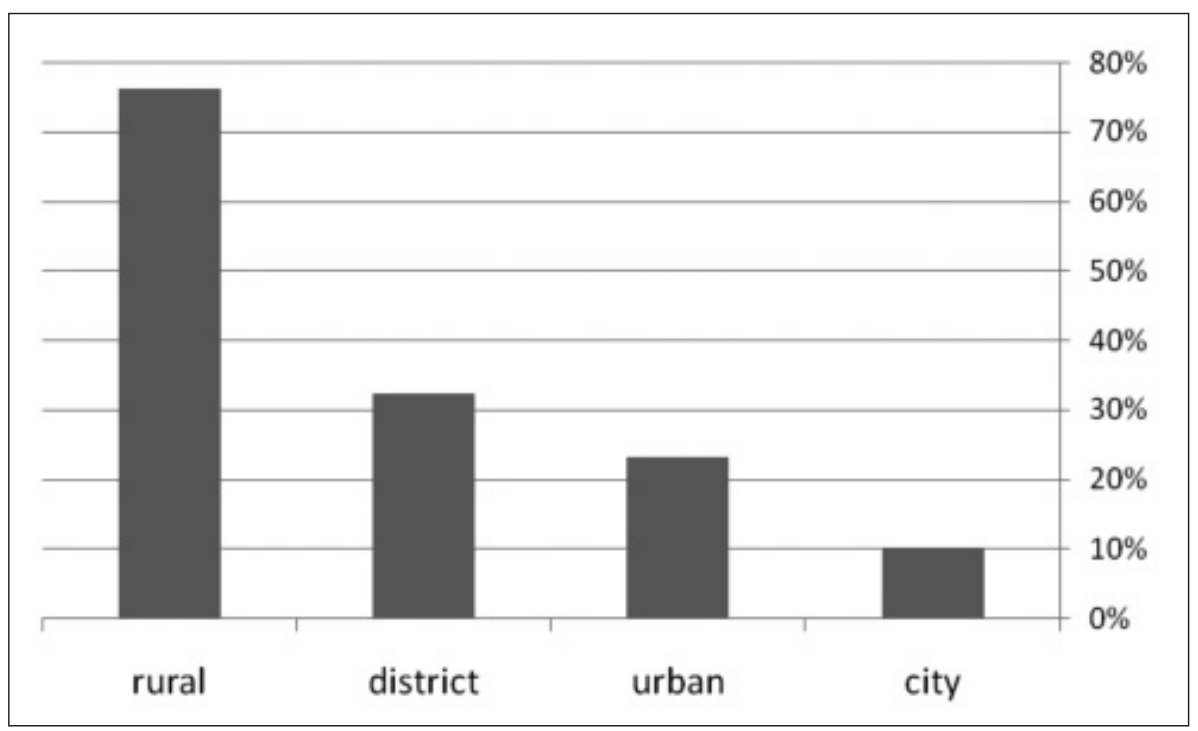

Figure 13: End of day float in absolute terms - averaged by store type

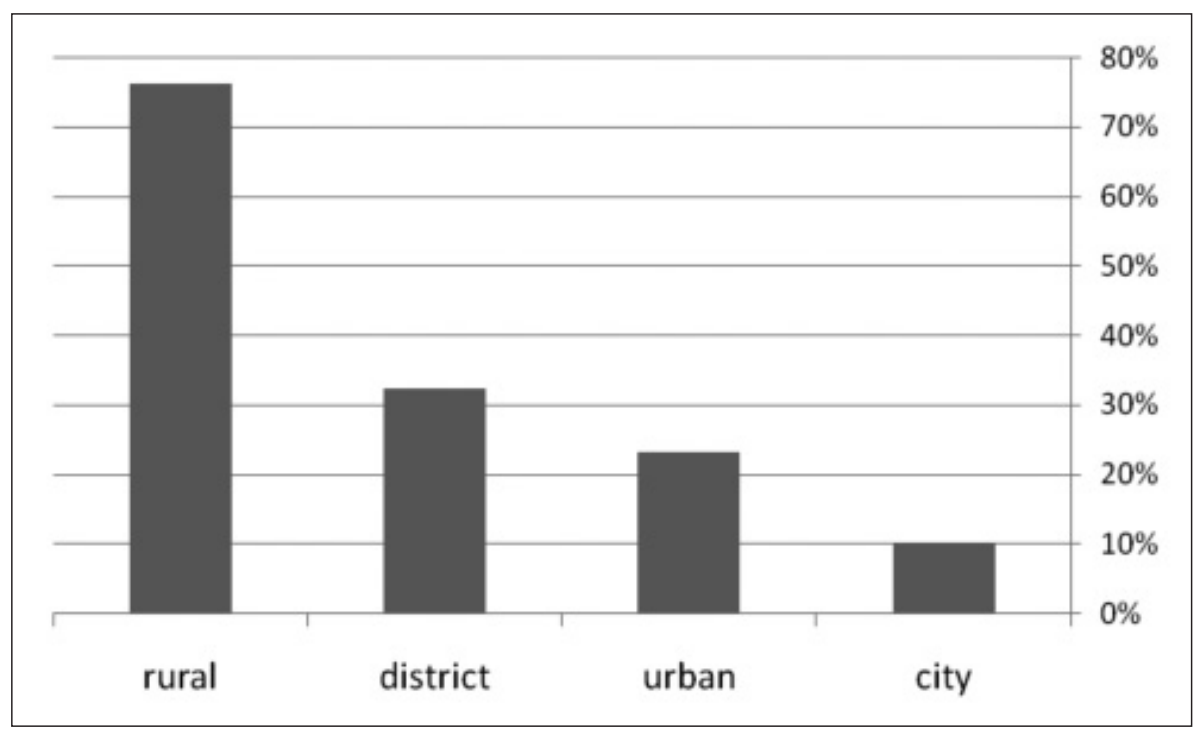


and city area stores are traders, buying and selling e-float and cash in more equal measure and rebalancing more frequently in the middle of the day (implying that the ratio of float to transaction volume should be lower as they turn over their float more often). Additionally, because some rural and district stores find it more difficult and costly to get cash, they can invest more in working capital as a percent of transaction volume (the combination of cash and e-float) and thus may have more e-float on hand at any given time.

Figure 13 shows that rural and district stores hold more e-float in absolute value at the end of the day as well (though because we don't know how much end of day cash they had, their end of day e-float balance does not necessarily reflect their working capital invested).

\section{Market days drive substantial transaction volumes}

Figure 14: Average daily client transaction volume by day of week for rural stores, as percent of weekly average

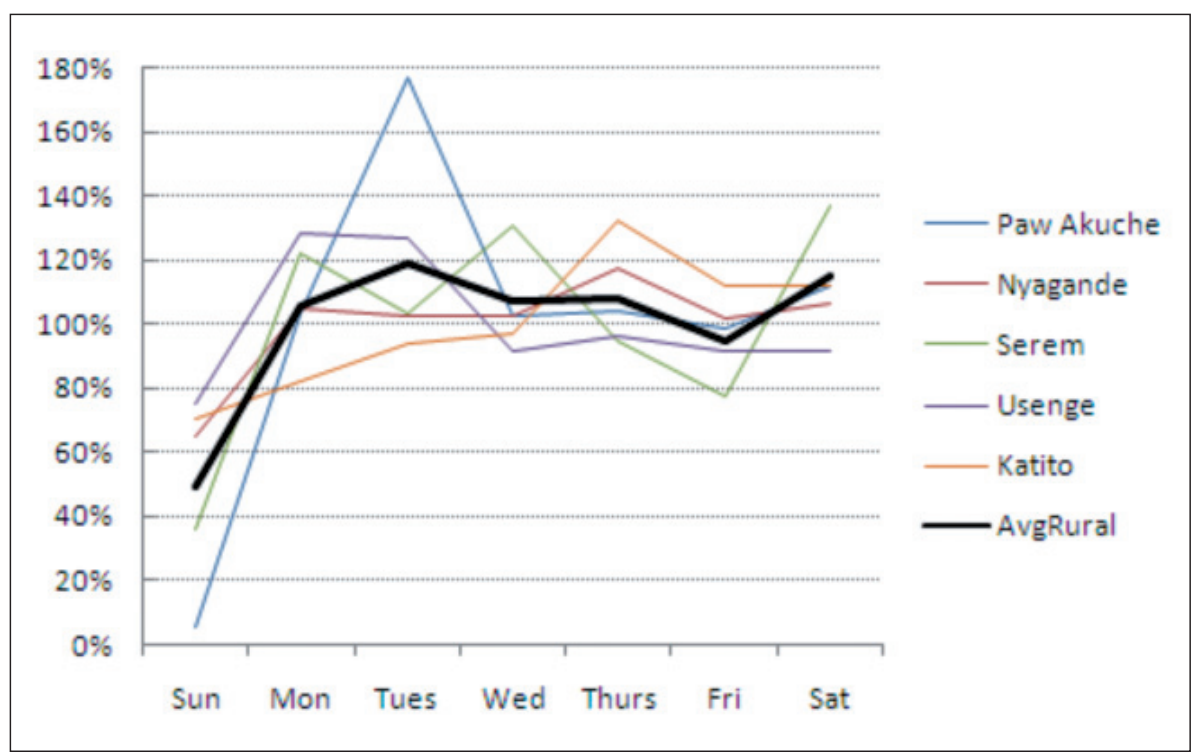

Figures 14 and 15 show the variation in daily client transaction volumes by day of week (relative to the daily average over the entire six month period) for stores in rural and urban markets, respectively. Sunday is a weak 
Figure 15: Average daily client transaction volume by day of week for urban stores, as percent of weekly average

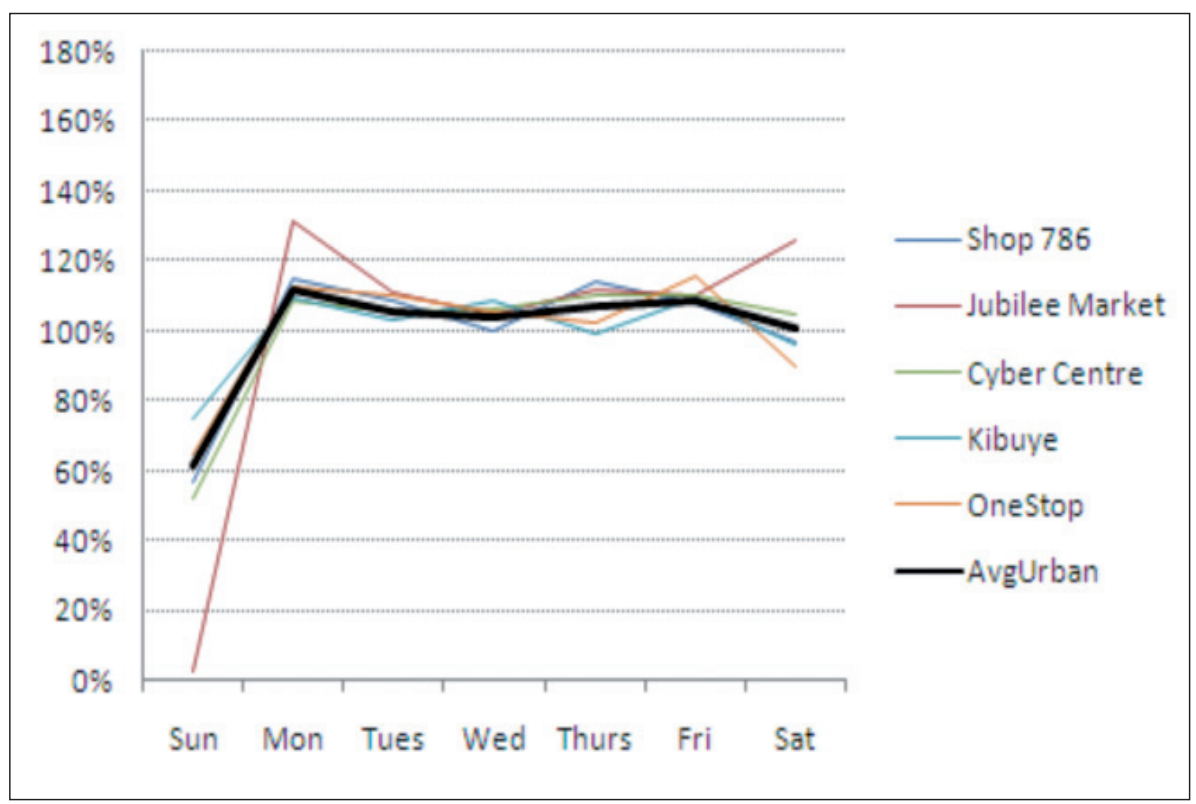

trading day, especially in rural towns, and many store owners are not even open. Rural towns typically have weekly markets, and so trading tends to be more concentrated on particular days of the week (Mondays and Tuesdays in Usenge, Tuesdays in Paw Akuche, Thursdays in Nyagande and Katito, Wednesdays and Saturdays in Serem). Urban markets are open daily (except Sundays) and hence trading is much more equally spaced across the week.

\section{There are important monthly variations}

Figure 16 shows the deviation in daily client transaction volumes by the day of the month (again, relative to the daily average over the entire six month period). There is a clear peak during the first week of the month, when salaries are typically paid. The variation from peak to trough can be as much as 40 percentage points driving a wide variation in cash needs and store profits over the course of the month.

Figure 17 shows the evolution of the daily trading volume by month over our six month sample period. Monthly oscillations are driven primarily by 
Figure 16: Intra-month variation in client transactions (percent daily variation in the median store trading volume in Ksh by day of month, excluding Sundays and Christmas when most stores are closed) ${ }^{9}$

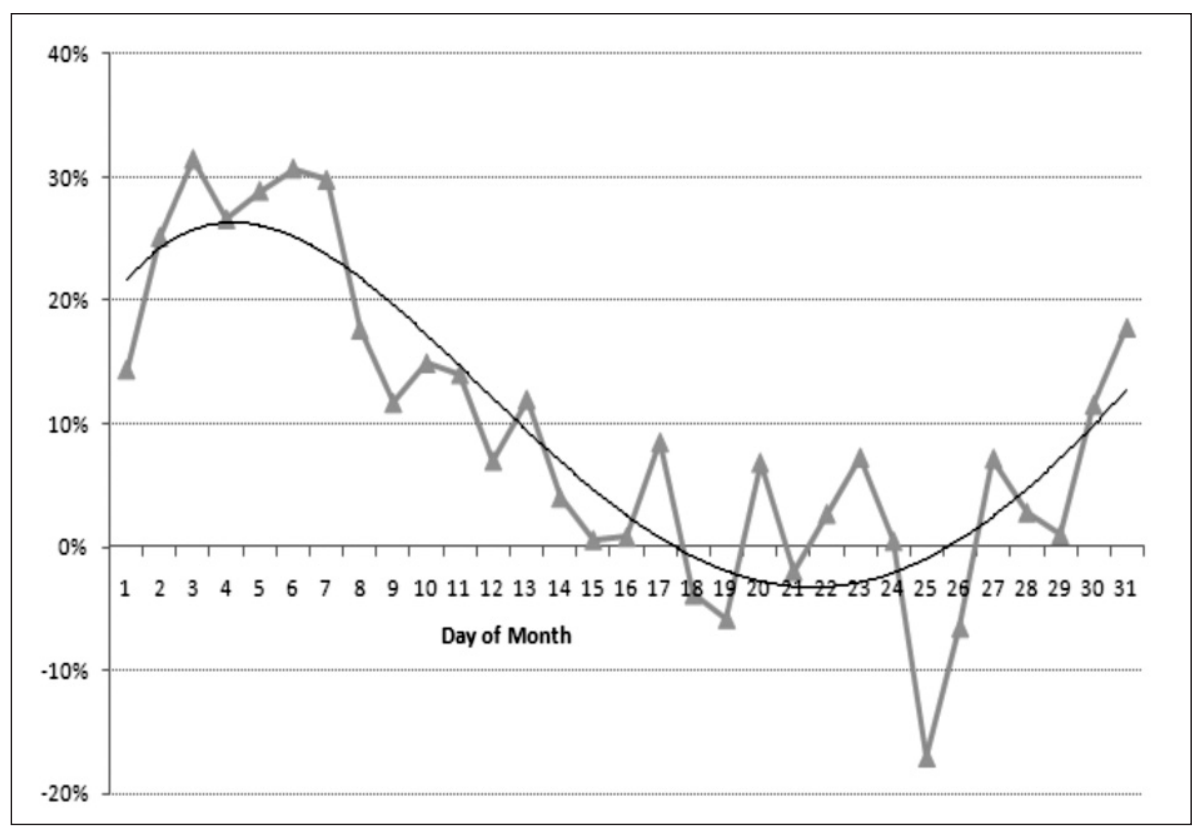

seasonal variations in the local business cycle which are particularly large for rural stores ${ }^{10}$. Customers appear to undertake more withdrawals in December around the Christmas holiday, more than compensating for a decline in transaction volumes in November. Many Kenyans from other parts of the country travel back to their family homes in and around Kisumu for the holidays. In December they will often transfer cash to relatives or to themselves before they leave so that they can withdraw it when they arrive in Kisumu. Much of the dip in November appears to be related to thrift in advance of the Christmas holidays and the fact that many relatives who would send cash save it to bring in person in December.

9 Each "day" on this graph reports the median value of the stores' percent deviation from their monthly averages for that day for the combined 6 months of data.

10 The large dip in July is related to the fact that government budgets are being reset at that time which slows government spending to a crawl and causes a drop off in business activity across Kenya. 


\section{Figure 17: Variation in client transactions by month (monthly trading volume in Ksh across all stores, as percent of period-wide average trading volume)}

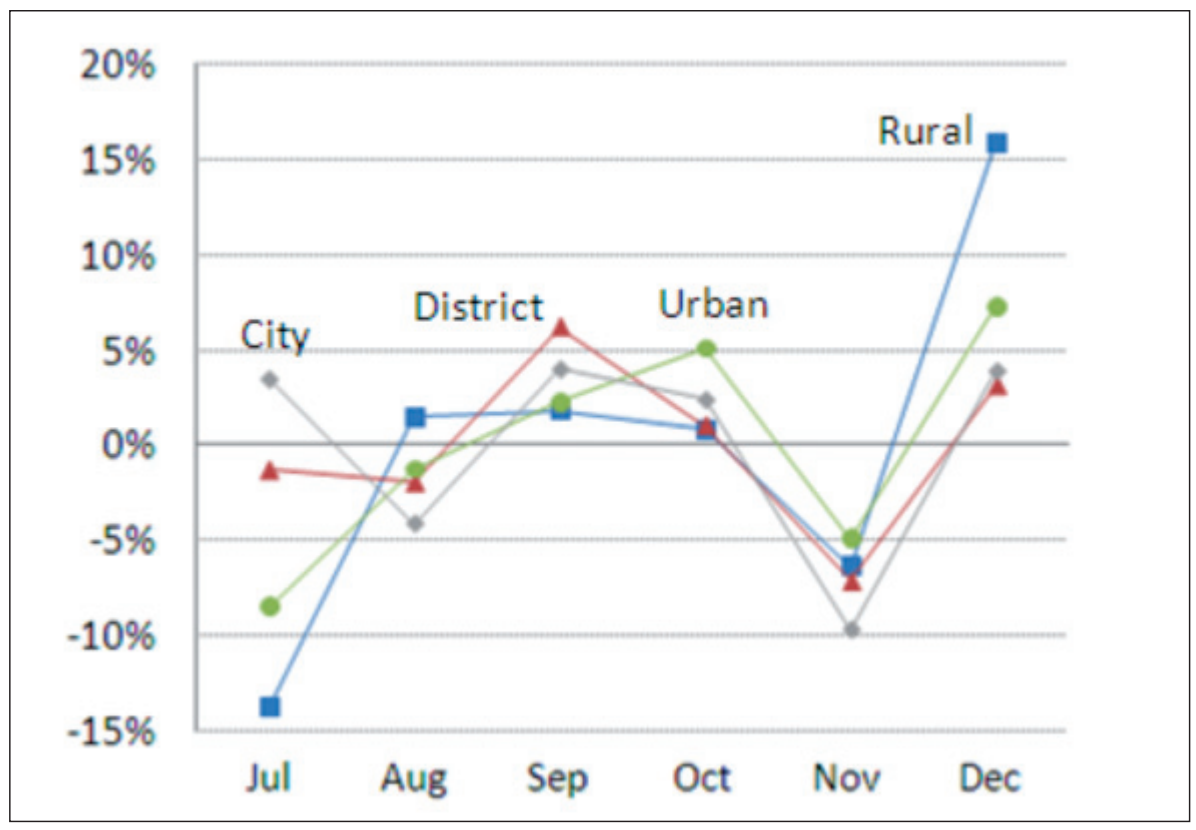

\section{There is substantial business volatility week-on-week, especially in non-urban environments}

Figure 18 shows the volatility in weekly client transactions volumes ${ }^{11}$. It shows that the business is most volatile in rural and district markets and least in the city centre. In rural and district stores, the number of transactions per week (the best indicator of weekly store revenues) regularly varies by up to about $20 \%$ from the average ${ }^{12}$. For store owners, this represents significant variation in their earnings.

11 This is based on the weekly number of transactions, and is computed as the standard deviation divided by the average over the six-month sample period. The coefficient of variation has been computed on weekly rather than daily transaction volumes in order to abstract from day-of-week effects which are particularly marked in rural markets as described in Figure 18.

12 Though the monthly cycle drives some of the variation in the business for all stores, it does not appear to drive the greater variation in rural store transactions vs. the other store types, which appears to be more a fundamental feature of the rural customer base. 
Figure 18: Volatility in weekly client transactions (weekly coefficient of variation)

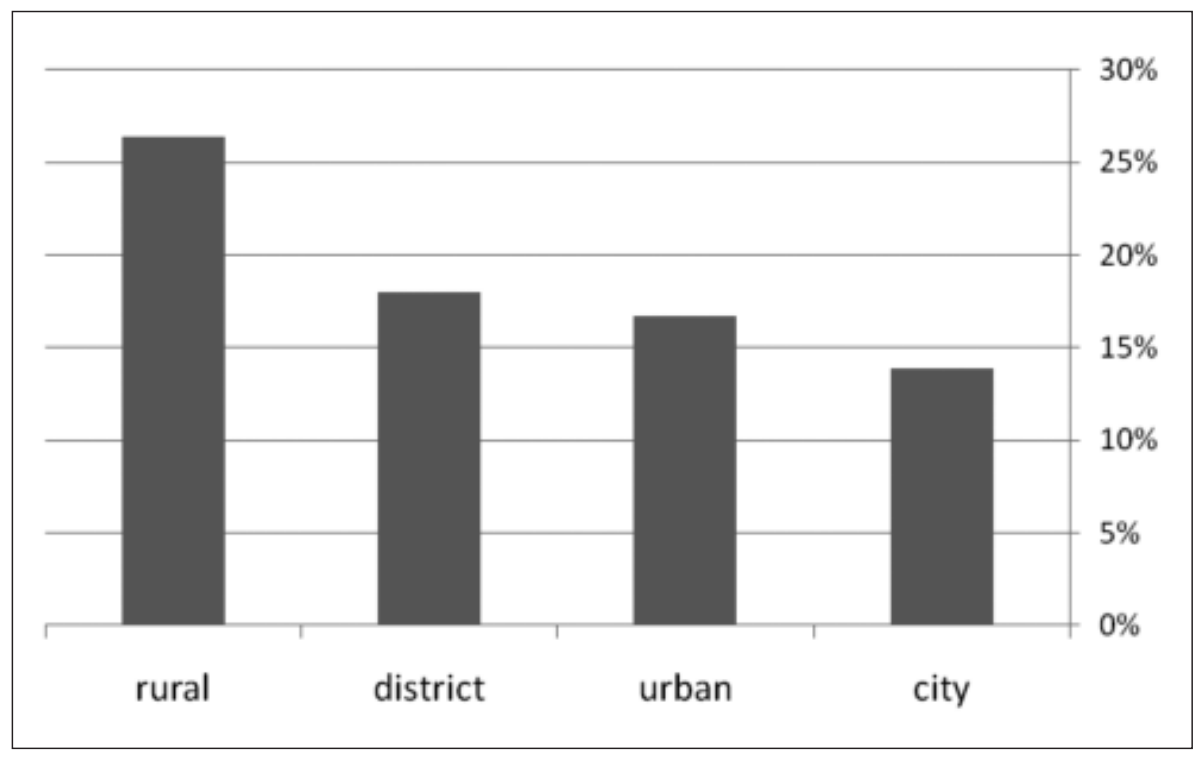

\section{The importance of customer service and service continuity}

Figure 19 shows daily transaction volumes for a particular urban market shop, Shop 786. In October 2009, the store was suspended by PEP from doing any transactions for one week because of some minor violations in their practices (they were not following proper procedures in checking customer IDs) The trading volumes show that, even after it was allowed to resume business, it took a few weeks for the store to recover the volume of business it had been transacting prior to the suspension. This is probably attributable to the fact that customers penalized Store 786 for not offering reliably continuous service and started going to other stores nearby (including two other PEP stores which are marked in the satellite photo in Figure 20). Conversations with M-PESA clients often confirm that service reliability is one of the most important attributes for an M-PESA outlet.

Figure 21 shows daily client transaction volumes for the Lake Market store, which is located in a prime location in the central business district of Kisumu. This can be contrasted against the average client transaction volumes for the other four city-center stores for all the other stores in Kisumu city center (see Figure 22). Lake Market does several multiples the volume of 
Figure 19: Daily transaction volume for Shop 786 (Ksh '000)

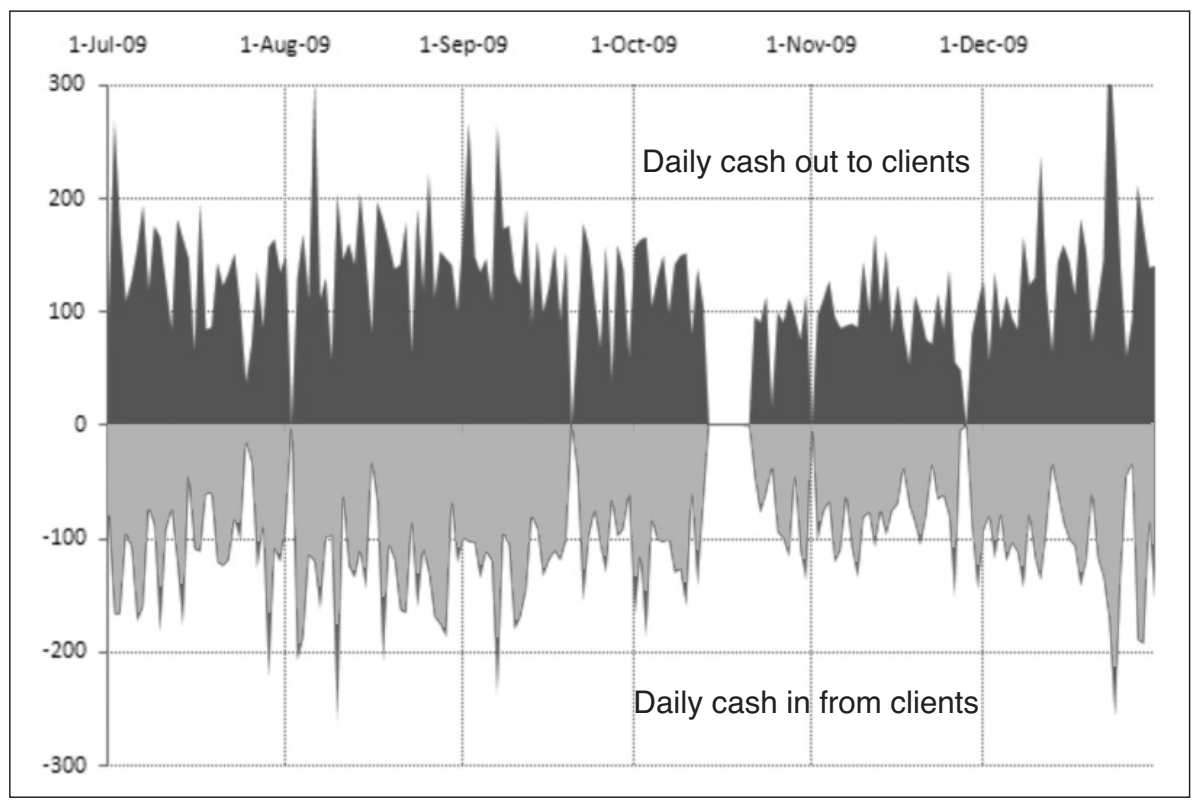

Figure 20: Location of three urban shops around Kisumu central market

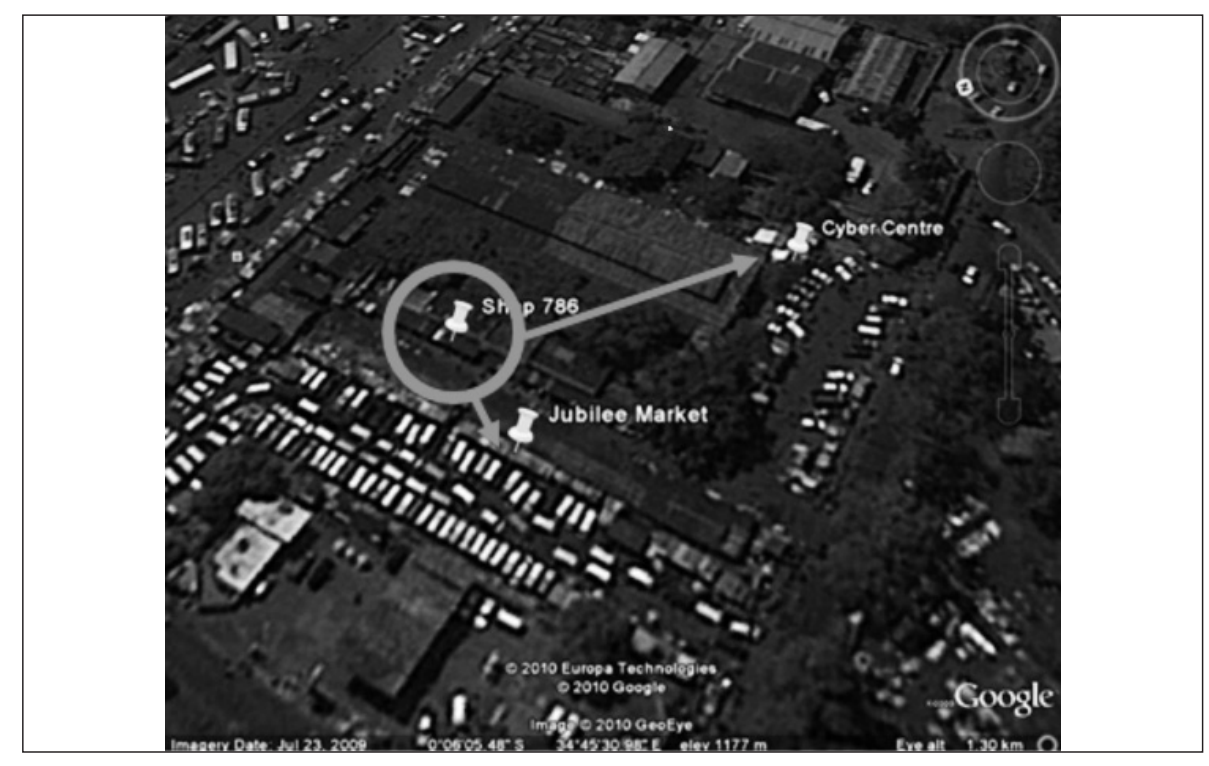


Figure 21: Daily transaction volume for Lake Market (Ksh '000)

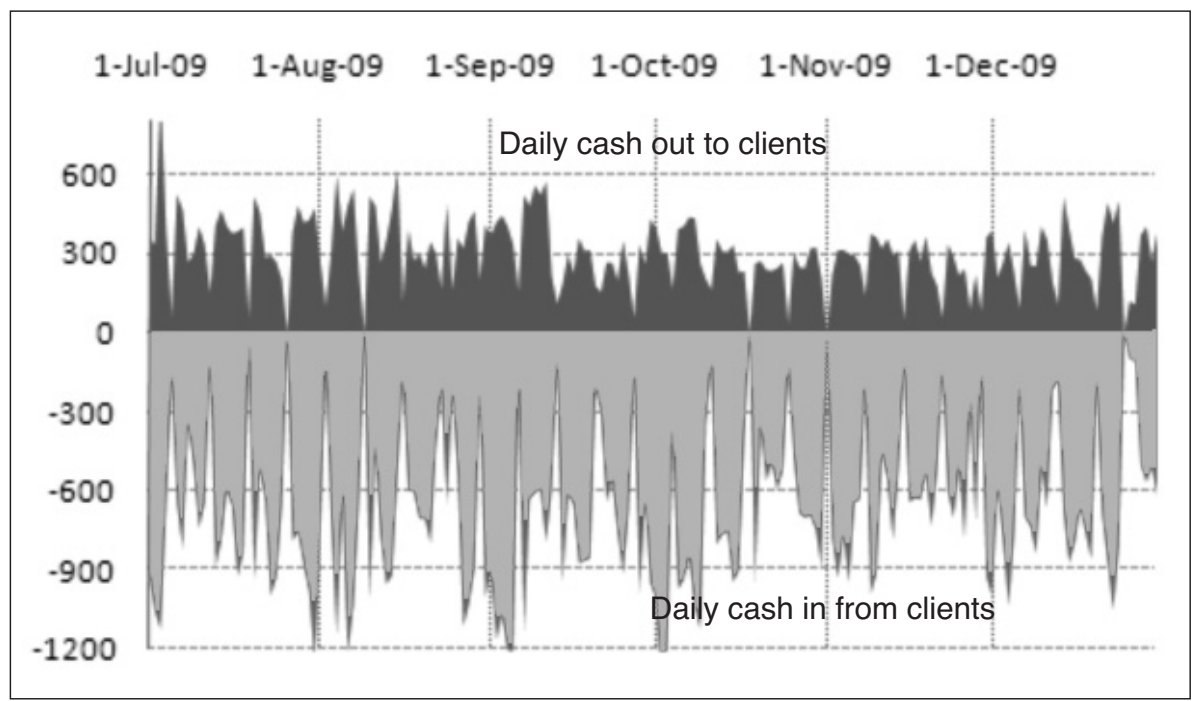

Figure 22: Daily transaction volume for the other four city-centre shops (Ksh `000)

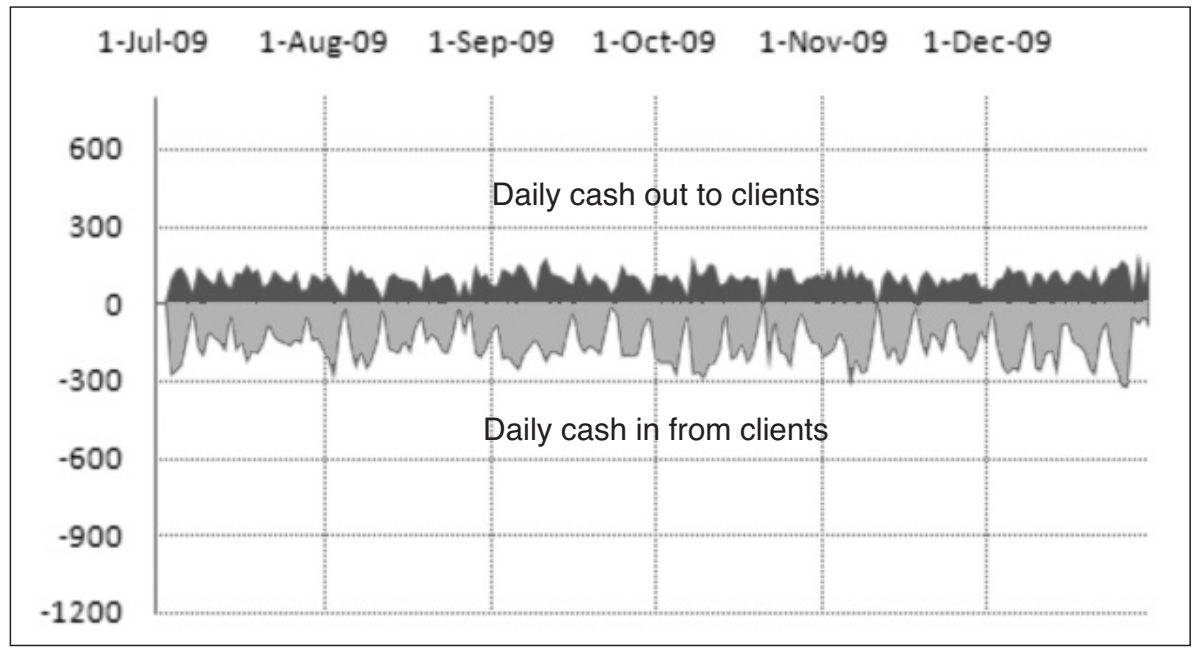

business of the other stores both due to its location but also due to its fastidious attention to customer service and investments in working capital (see Section 5.2). 


\section{FURTHER OBSERVATIONS FROM INTERVIEWS AND CASE STUDIES}

Here we present a set of case studies and observations generated from interviews of clients, store employees, agent owners and managers, and PEP Intermedius staff which provide illustrative details about the difficulties agents fact in managing liquidity.

\subsection{Three trips to rebalance cash and e-float}

The following are three examples - based on interviews of store managers and their employees - of stores' daily cash or e-float buying trips, representing a typical level of cost, risk, and difficulty for the store owners.

Paw Akuche is a PEP-owned store located in a rural village about 40 minutes by bus from Kisumu and PEP headquarters. Round trip bus fare is 200Ksh. Lilian, one of the store's two employees, lives in Kisumu and so can stop by PEP on her way to work (PEP is nice enough to pay her bus fare because this is a PEP-owned store). On Tuesdays (which are market days in the village) and on other heavy transaction days, Lilian must make an additional trip into Kisumu to get more cash, leaving Gladys the store manager to deal with the customers by herself. Store owners often look for creative arrangements to move cash, such as having a store employee get it on the way to work, but these arrangements often depend on the employee staying with the store and require that owners find someone they can trust.

Cyber Center is no more than a 10 minute walk or 2 minute scooter ride to the PEP center (scooter rides cost 10Ksh or 13ф). This allows Cyber Center to rebalance an average of 2.8 times per working day (see Figure 3), one of the more frequent in our sample. The only time when a trip to PEP is inconvenient is when the owner, Betty, is away in which case if they need e-float they can phone in a request to PEP and pay cash at the end of the day (here PEP is essentially loaning them working capital for the day at zero interest). If they need cash, they would be forced to close the store for 15 minutes and surely lose a few customers while they were away.

Luanda is a District store, located an hour or so from Kisumu by bus but only 5 minutes away from a local CBK branch. Despite the location, sending or receiving cash through a bank branch is more difficult for an agent and can require one of the PEP HQ staff to make a simultaneous trip to the bank on the other end where there may be lines and other delays of up to 3-4 
hours while the cash is moved between the agent's account and PEP's. As most M-PESA agents are open till 7pm or later, a surge of customers late in the day can leave them stranded for cash if the bank branch has already closed. This has happened to Luanda on a few occasions.

\subsection{Lake Market Store, case study of a high volume store}

Lake Market Store is located in the heart of the city center and just across from the district offices of the local power company Kenya Power and Light (KPL) which is good for business for a variety of reasons: customers often need to deposit to pay their bills using M-PESA; KPL sometimes pays employees with M-PESA; and KPL contractors often need to deposit to pay their sub-contractors, suppliers, and day laborers.

But in the M-PESA agent business, location isn't everything. Mollie Achieng, the owner of Lake Market reports that they have invested nearly $300,000 \mathrm{Ksh}$ (US\$4,000) in e-float working capital, twice the amount that PEP requires of its stores (and even still, they visit PEP 5 or more times per day). Because of this investment, Mollie has a reputation for always being able to meet the cash and float needs of her customers. She has also invested in a phone for customers to use who don't own one (some only have a SIM card). She has even gained her customers' trust to the extent that when the M-PESA system is down for a few hours, or even just when the line in front of her store is long, busy customers will show their ID and drop envelopes of cash with the clerk for processing later when the system is back up. Thus, due to high levels of customer satisfaction and trust, Lake Market is able to continue operating - and continue earning commissions - even when the M-PESA system is down.

Due to the high volume of customers, Lake Market sometimes grosses over $100,000 \mathrm{Ksh}$ in a month (US\$1300) of which they might take home 65,000Ksh (US\$850) after taxes and PEP fees ${ }^{13}$.

\subsection{Case study of Gaudencia, Owner of Three M-PESA Retail Outlets}

Gaudencia is a 45 year old widower and mother of 3 children who owns three M-PESA stores near Kisumu in western Kenya. She is semi-literate (having achieved primary standard 4) speaks no English, and previous to getting into the M-PESA agent business, sold chickens in the Kisumu market.

13 Mollie reports that her main business expenses are one employee salary of 6,000Ksh (US\$80) and rent of 10,000Ksh (US\$130), leaving a substantial profit. 
Figure 23: Daily transport route for Gaudencia and costs associated with each leg of the journey

\section{Gaudencia's Daily Route with 1-way Travel Costs}

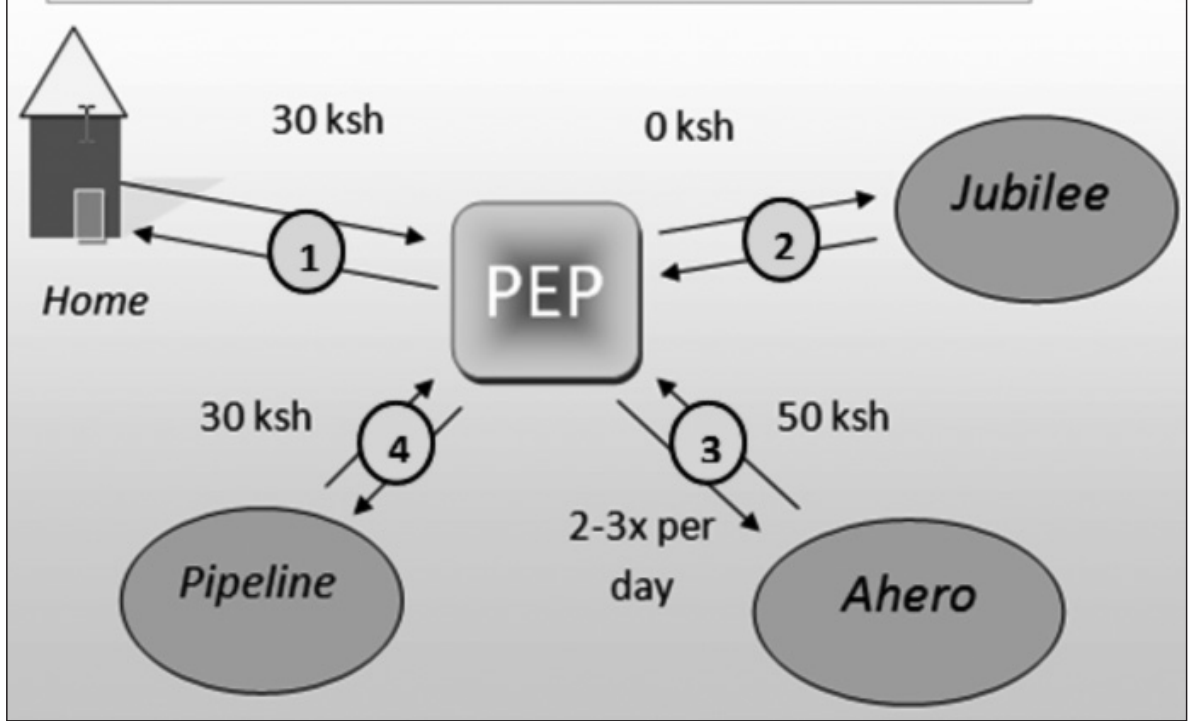

One of her stores - Jubilee Market - is located in the Kisumu produce market. Her Ahero and Pipeline stores are located outside Kisumu, each at a distance of about 30 minutes by bus. The Jubilee and Ahero stores are staffed by her daughter and son, respectively. Gaudencia is constantly on the move, shuttling back and forth between her stores and the headquarters of PEP (the M-PESA distributor who manages her) to move cash and e-float where it's needed most. Like most agents, she understands that customer service - being able to provide cash or e-float when needed - is key to a business where there is likely to be another M-PESA agent literally in the adjacent shop (see Figure 2 which shows some stores are less than 5 meters apart, this is quite typical in Kenya). The fact that her son and daughter staff two of her three stores makes it easier for her to absent herself. Gaudencia's typical daily rounds are represented by the diagram in Figure 1 where the amounts are Kenyan Shillings and represent the one way bus fare associated with each leg of the trip.

In the morning, Gaudencia first travels from home to pick up cash at PEP (1), then walks from PEP to Jubilee Market and back (2), then back and forth 
to both Ahero (3) and Pipeline (4). She is usually finished with the full circuit by $2 \mathrm{pm}$ at which point she returns to Ahero for a second trip. On Tuesday, which is Ahero's market day, she starts with Ahero in the morning, and makes 3 full trips, in addition to the regular circuit, by the time the day is done. In the course of a day, Gaudencia can spend $300-375 K$ sh (US\$4-\$5) on bus fare (this would be a typical daily wage in Kisumu) and reports that the cost of travel in time and money are the most aggravating aspect of her day. On one leg of each visit she will be carrying cash to or from the store, and often the value of cash she carries exceeds $75,000 \mathrm{Ksh}(\mathrm{US} \$ 1,000)$. Despite the relatively large sums she carries, she has never been robbed and does not report feeling like security is a major risk. For her troubles, Gaudencia sometimes nets over $75,000 \mathrm{Ksh}(\mathrm{US} \$ 1,000)$ per month in transactional revenue from her 3 stores.

\section{CONCLUSIONS}

From the nine observations listed above, we can draw three high-level conclusions:

- Stores require quite intense daily liquidity management support. They must rebalance on at least $60 \%$ of days (almost every day that they are open), and often several times per day. This represents a significant cost to stores, as a clerk must leave the store to carry or pick up cash. In the introduction, the section 2.2 titled Agent costs and risks in liquidity management gives greater detail on the main costs to agents of providing liquidity.

- Rural areas face greater difficulties. Rural stores face special challenges as they have to deal with a triple whammy: (i) their commissions are typically lower because they handle fewer and smaller transactions; (ii) their transactions tend to be more lopsided towards cash out reflecting typical transfer patterns from urban to rural areas, so they have fewer opportunities for customer transactions naturally offsetting each other; and (iii) they tend to be located much further away from bank branches, which increases their travel and time costs each time they need to rebalance their liquidity. It would be appropriate to compensate these adverse effects with higher per-transaction commissions for rural stores. In the M-PESA context this happens naturally, insofar as withdrawal transactions incur a higher commission than equivalently-sized deposit transactions (total channel commissions of $10 \mathrm{Ksh}$ versus $15 \mathrm{Ksh}$, respectively, for transactions of less than $2500 \mathrm{Ksh}$ ). Since rural stores deal with predominantly cash out transactions, they benefit from this commission asymmetry. 
- There is evidence of market discipline between stores. Customers face choice in their selection of M-PESA outlets. Figure 2 shows that most stores are within 100 meters of another M-PESA outlet. They seem to exercise this choice deliberately, favoring certain stores offering exceptional service with substantial trading volumes despite their being other stores nearby (see Section 5.2 on the Lake Market Store). On the other hand, customers seem to punish stores that are not able to offer consistent service levels. The example of Shop 786 (see Figure 20) which appears to have been disciplined by customers for shutting down for 4 days shows the importance of market discipline.

These three conclusions have implications for how policy makers and practitioners should approach mobile money. Practitioners wishing to set up mobile money schemes would do well to note the high costs of agent network management and should commit themselves to sticking it out through the early days when these costs will overwhelm revenues. Policy makers and especially regulators should recognize the high network management costs when thinking about competition policy in the mobile money space since higher levels of competition at the network level will erode margins reducing the incentive to make this investment (especially in rural areas where the positive impact on financial access will be greatest). That said, the evidence we have shown here seems to indicate that competition at the agent level (between agents on the same network) may promote higher levels of customer service and reduce concerns for consumer protection as agents vie for a limited local pool of customers.

Going forward, researchers should seek greater clarity on the systemic effects of competition at the agent and network levels, and at the product level (riding on top the agent network) and the consumer welfare implications of different regulatory frameworks. The dynamics of competition at all three of these levels are complex and the simple maxim "more competition is better" will not likely hold in each case.

\section{References}

Financial Sector Deepening Trust of Kenya [FSD-K], 2009, "FinAccess National Survey 2009: Dynamics of Kenya's Changing Financial Landscape", June.

Davidson N. and P. Leishman, 2010, "GSMA Handbook on Agent Networks", GSMA Mobile Money For the Unbanked.

De Laat, Joost, 2005, “Moral Hazard and Costly Monitoring: The Case of Split Migrants in Kenya", Job Market Paper. 
Jack B. and T. Suri, 2009, "Mobile Money: the Economics of M-PESA", Working paper (author's web page).

Jack B. and T. Suri, 2010 a, "The Economics of M-PESA: An Update", Working paper (author's web page).

Jack B. and T. Suri, 2010 b, "The Impact of M-PESA: Results from a Panel Survey of Mobile Banking Use among Kenyan Households", Presentation (author's web page).

Kendall J., 2010, "A Penny Saved: How do Savings Accounts Help the Poor?", Financial Access Initiative, Focus Note.

Mas I. and A. Ng'weno, “Three Keys to M-PESA's Success: Branding, Channel Management and Pricing", Journal of Payments Strategy and Systems, Vol. 4, No. 4, December.

Mas I. and D. Radcliffe, 2010 a, "Scaling Mobile Money", Working Paper.

Mas I. and D. Radcliffe, 2010 b, "Mobile Payments Go Viral: The Story of M-PESA", in Yes Africa Can: Success Stories from a Dynamic Continent, World Bank, forthcoming.

Morawczynski O., 2009, "Exploring the Usage and Impact of "Transformational" Mobile Financial Services: The Case of M-PESA in Kenya", Journal of Eastern African Studies, Vol. 3, No. 3, pp. 509-525.

\section{Résumé}

M-PESA est un remarquable système de paiement mobile lancé au Kenya il y a trois ans. Les utilisateurs sont en mesure de s'envoyer de l'argent les uns les autres commodément de leurs M-PESA en utilisant uniquement leur téléphone portable. L'une des clés du succès de M-PESA est la disponibilité d'un vaste réseau de magasins de détail qui acceptent les dépôts M-PESA et les retraits, c'est à dire qu'ils sont prêts à échanger de l'argent comptant et de la valeur électronique. Ce sont les magasins qui fournissent des liquidités au système, et ils reçoivent une commission par M-PESA pour ce service. Derrière le magasin il existe un réseau d'intermédiaires qui organisent la logistique entourant la gestion de la trésorerie. Dans cet article, nous examinons les données transactionnelles quotidiennes de six magasins M-PESA au Kenya occidental, complétées par des études de cas et des interviews aves des directeurs de magasin M-PESA et des employés afin de mieux comprendre la gestion des besoins de liquidité de ces magasins. Nous examinons comment les besoins de liquidité varient selon le lieu et le jour de la semaine / du mois, et par le niveau de service offert par le magasin. Nous constatons que les magasins ont besoin d'une intense gestion journalière des liquidités pour maintenir les niveaux de service à la clientèle et que cela est plus difficile dans les zones rurales. Nous observons aussi la discipline de marché pour les agents qui ne peuvent pas maintenir certains niveaux de service.

Mots clés: Mobile Money, Agent Banking, M-PESA, Kenya, Réseaux d'Agent.

Classification JEL: G21, L81, L96, M2, M13, M15. 